\begin{tabular}{|l|l|}
\hline $\begin{array}{l}\text { 2. To: (Receiving Organization) } \\
\text { DISTRIBUT ION }\end{array}$ & $\begin{array}{l}\text { 3. From: (Originating Organization) } \\
\text { INTERIM STABILIZATION }\end{array}$ \\
\hline $\begin{array}{l}\text { 5. Proj./Prog./Dept./Div.: } \\
\text { INTERIM STABILIZATION }\end{array}$ & $\begin{array}{l}\text { 6. Design Authorthy/Design Agent/Cog. Engr.: } \\
\text { W. F. ZUROFE }\end{array}$ \\
\hline $\begin{array}{l}\text { 8. Originator Remarks: } \\
\text { ATTACHED IS A TEST REPORT FOR THE ACCEPTANCE TESTING OF PUMPING AND } \\
\text { INSTRUMENTATION CONTROL SKID "L". }\end{array}$
\end{tabular}

11. Receiver Remarks:

NONE

\section{A. Design Baseline Document? $\bigcirc$ Yes $\bigcirc$ No}

\section{Related EDT No.:}

N/A

7. Purchaso Order No.

$\mathrm{N} / \mathrm{A}$

9. Equip./Component No.:

$\mathrm{N} / \mathrm{A}$

10. System/Bldg./Facility:

241-G

12. Major Assm. Dwg. No.

N/A

13. Permit/Permit Application No.:

$\mathrm{N} / \mathrm{A}$

14. Required Response Date:

$11 / 05 / 99$

\begin{tabular}{|l|l|}
\hline 15. \\
\hline $\begin{array}{c}\text { (A) } \\
\text { Ifem } \\
\text { No. }\end{array}$ & (B) Document/Drawing No. \\
\hline 1 & RPP -5056 \\
\hline & \\
\hline & \\
\hline & \\
\hline & \\
\hline & \\
\hline & \\
\hline
\end{tabular}

DATA TRANSMITTED

(F)

(G)

\begin{tabular}{|c|c|c|}
\hline (H) & (I) \\
\hline 1 & 1 \\
\hline & $\begin{array}{c}\text { Origi- } \\
\text { nator } \\
\text { Dispo- } \\
\text { stion }\end{array}$ & $\begin{array}{c}\text { Receiv- } \\
\text { or } \\
\text { Dispo- } \\
\text { sition }\end{array}$ \\
\hline & & \\
\hline & & \\
\hline
\end{tabular}

16.

\begin{tabular}{c|c|c|}
$\begin{array}{c}\text { (C) Sheet } \\
\text { No. }\end{array}$ & (D) Rev. \\
No. & (E) Titte or Description of Data Transmitted
\end{tabular}

\begin{tabular}{|l|l|}
\hline N/A & 0 \\
\hline & \\
\hline & \\
\hline & \\
\hline & \\
\hline & \\
\hline
\end{tabular}

TEST REPORT FOR ACCEPTANCE TEST PROCEDURE FOR PUMPING INSTRUMENTATION AND CONTROL SKID "L"

\begin{tabular}{|c|}
\hline Approval Designator (F) \\
\hline E, S, Q, D OR N/A \\
(See WHC-CM-3-5, \\
Sec. 12.7)
\end{tabular}

17.

\begin{tabular}{|c|c|c|}
\hline $\begin{array}{l}\text { (G) } \\
\text { Rea- } \\
\text { son }\end{array}$ & $\begin{array}{c}(\mathrm{H}) \\
\text { Disp. }\end{array}$ & (K) Signature \\
\hline 1 & & Design Authority W. F. ZUROI \\
\hline 1 & & Design Agent B.R. JOHNS \\
\hline 1 & & Cog. Eng. B.R. JOHNS $\boldsymbol{b}$ \\
\hline 1 & ) & Cog. Mgr. M.R. KOCH $n /$ \\
\hline 1 & 1 & QA M.C. IdESTMANh \\
\hline 1 & | & Safety F.A. ZAK \\
\hline & & $\mathrm{N} / \mathrm{A}$ \\
\hline
\end{tabular}

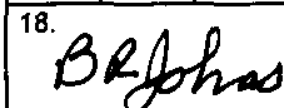

B.R. JOHNS Signature of EDT Originator

$$
\text { NIRIC }
$$
111199 Date
M.R. KOCH Authorized Representative for Receiving Organization

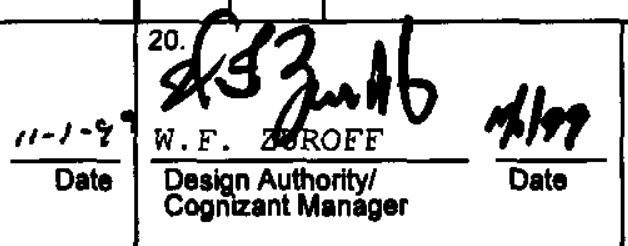

Disposition (H) \& (I)

$\begin{array}{ll}\text { 1. Approved } & \text { 4. Reviewed no/comment } \\ \text { 2. Approved w/comment } & \text { 5. Reviewed w/comment } \\ \text { 3. Disapproved w/comment } & \text { 6. Recelpt acknowledged }\end{array}$

2. Approved w/comment

6. Receipt actomment

KEY
21. DOE APPROVAL (if required)

Ctr No. N/A

Approved

Approved w/comments

Disapproved w/comments 


\title{
TEST REPORT FOR ACCEPTANCE TEST PROCEDURE FOR PUMPING INSTRUMENTATION AND CONTROL SKID "L"
}

\author{
M. R. коCH \\ COGEMA ENGINEERING CORPORATION \\ Richland, WA 99352 \\ U.S. Department of Energy Contract DE-AC06-96RL13200 \\ EDT/ECN: 624847 \\ UC: \\ Org Code: 74D00 \\ Charge Code: 103361 \\ B\&R Code: EW3120071 \\ Total Pages: 63 \\ Key Words: PICS, SALT WELL, SKID, INTERIM STABILIZATION, TESTING
}

\begin{abstract}
:
This is a Test Report for Acceptance Test procedure (ATP) RPP-5055.

This test report provides the results of the inspection and testing of the new Pumping Instrumentation and Control (PIC) skid designed as "L". The ATP was successfully completed. A copy of the completed ATP is in the Appendix of this document.
\end{abstract}

TRADEMARK DISCLAIMER. Reference herein to any specific commercial product, process, or service by trade name, trademark, manufacturer, or otherwise, does not necessarily constitute or imply its endorsement, recommendation, or favoring by the United States Government or any agency thereof or its contractors or subcontractors.

Printed in the United States of America. To obtain copies of this document, contact: Document Control Services, P.O. Box 950, Mailstop H6-08, Richland WA 99352, Phone (509) 372-2420; Fax (509) 376-4989.
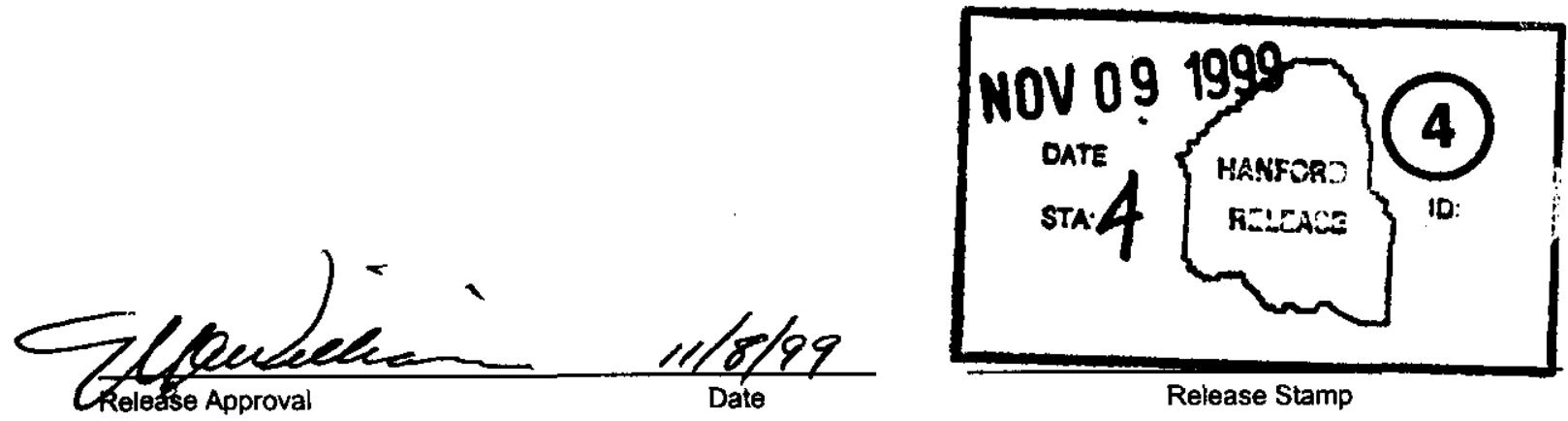

Approved For Public Release 
RPP-5056

REVISION 0

\section{TEST REPORT FOR ACCEPTANCE TEST PROCEDURE FOR PUMPING INSTRUMENTATION AND CONTROL SKID "L"}

\subsection{INTRODUCTION}

This test report provides the results from the performance of Acceptance Test Procedure (ATP) RPP-5055, for Pumping and Instrumentation Control (PIC) skid " $L$ ". The ATP verifies the proper construction of the PIC skid " $L$ " by Site Fabrication Services along with proper programming of the Programmable Logic Controller (PLC) by engineering. New PIC skid " $L$ " will be used for the pumping of tank U-105. A copy of the actual test results is in the Appendix of this document.

\subsection{DESCRIPTION OF TEST}

The test was performed at the Site Fabrication Services location. The ATP ensured the PIC skid was assembled and functioned as per the design drawings. Inputs to the skid were simulated to ensure proper equipment connections and wiring.

The ATP document provided detailed instructions for each test step and spaces for recording the data and signoffs. A copy of the test results including exceptions is in the Appendix.

\subsection{TEST METHOD AND TEST EQUIPMENT}

The ATP detailed the test methods and the test equipment to be used for testing. Test equipment identification and calibration dates are recorded on the ATP data sheets. Quality Control and Engineering witnessed the performance of the ATP. 
RPP-5056

REVISION 0

\subsection{TEST RESULTS}

The ATP was successfully completed. Discrepancies in the test procedure were listed as exceptions. All the exceptions identified became part of the ATP and are in the Appendix along with the ATP results. All exceptions were reviewed, resolved and signed off as closed for this ATP.

A National Electrical Code (NEC) inspection was performed as part of the ATP. The NEC inspector accepted the electrical power portion of the skid and placed a blue acceptance sticker on the distribution panel. A Pressure Vessel inspector checked the water and air compressor tanks along with the associated relief valves. The installation of these tanks was acceptable. A copy of the NEC and Pressure Vessel inspection reports are in the Appendix of this document.

\subsection{CONCLUSIONS AND RECOMMENDATIONS}

The PIC skid is found to be ready for field operation. All exceptions were resolved. An Operational Test Procedure (OTP) will be performed after the skid is set up for field configuration.

\subsection{REFERENCES}

RPP-5055, REVISION 0, ACCEPTANCE TEST PROCEURE FOR PUMPING AND INSTRUMENTATION CONTROL SKIDS, Lockheed Martin Hanford Corporation, Richland, Washington.

2H9903386, Site Fabrication Services work package. 
RPP-5056

REVISION 0

\subsection{APPENDIX}

Copy of ATP, RPP-5055, Revision 0.

NEC Inspection Report

Pressure Vessel Inspection Report 


\subsection{PREREQUISITES}

\subsection{DRAWING VERIFICATION}

A check of the constructed skid is to be compared to either the redlined drawings or the final unreleased skid drawings. Engineering and Quality Assurance shall verify the accuracy of the essential and support drawings. Engineering shall determine a resolution for all discrepancies by either correcting the drawings or changing the equipment.

The following drawings shall be walked down for verification of proper construction of the skid:

4.1.1 Wire terminations and wiring labeling on drawings H-14-103538, sheets 7 through 12 and H-14-103541, sheet 5:

4.1.2 Panel board arrangement on drawing H-14-103537.

4.1.3 Flow diagrams on drawings $\mathrm{H}-14-103538$, sheet 5 and H-14-103543.'-

Drawing verification completed. (Final drawing release is not required to continue with this ATP.)

* See exception *1

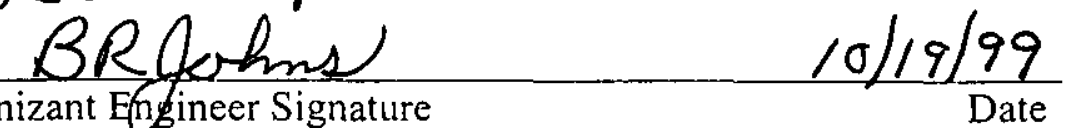

Cognizant Engineer Signature

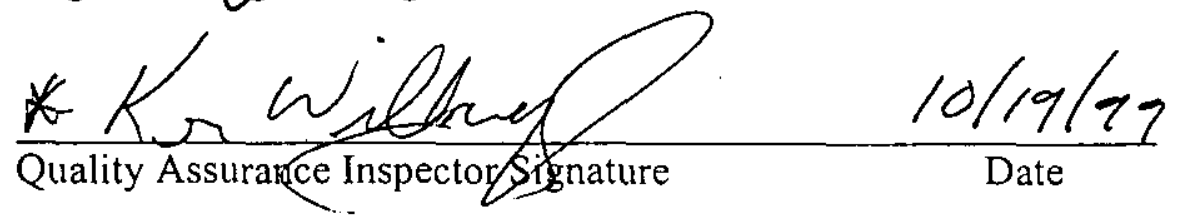




\subsection{PRESSURE VESSEL INSPECTION}

A pressure vessel inspection by a third party inspector is required for the air compressor, the air receiver tank and relief valves located in the air compressor cabinet and the water tank and relief valves in the water cabinet. The inspection is to verify that the equipment meets National Codes for pressure vessels. An outside-certified inspector will perform this inspection. (This inspection shall be completed prior to checking the air compressor and water systems.)

Pressure vessel inspection report received. (The ATP can continue before the report is received, but must be received prior to performing section 5.8.)

Report \# TPI.WT.139,140

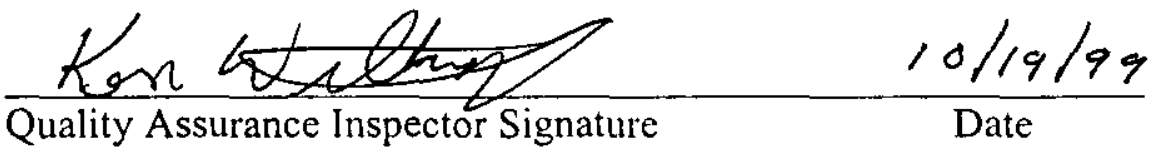

\subsection{NATIONAL ELECTRICAL CODE (NEC) INSPECTION}

4.3.1 An NEC inspection shall be performed to verify compliance to NFPA 70, latest version.

4.3.2 Areas in particular to be inspected are 480vac and 120vac wiring and grounding.

4.3.3 An NEC inspection sticker is to be placed inside the panel board door upon the NEC inspector's acceptance of the electrical portion of the skid.

The NEC inspection performed and an NEC inspection sticker placed on the panel board door. (This needs to be completed prior to the section 5.0 functional checks.)

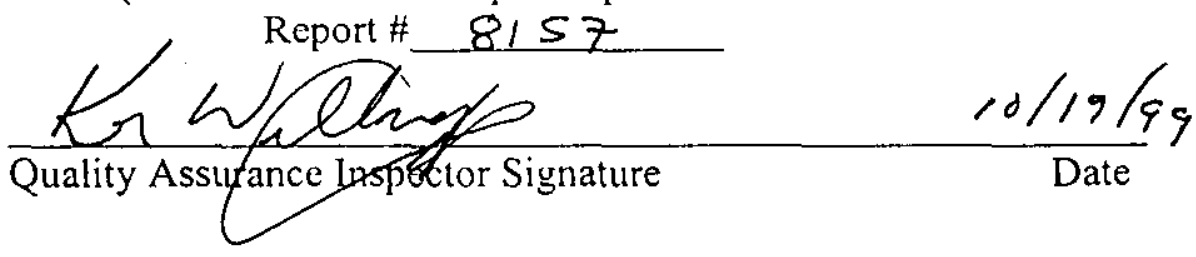

PAGE A-2 


\subsection{SUPPLIES}

The following supplies are required for this ATP:

Note: Test sections may commence prior to assembly of all the test equipment. Engineer and/or PIC are to ensure test equipment available prior to the start of each section.

4.4.1 Volt/ohm meter (VOM): Portable, 0-600vac.

Calibration No. 817.45 .08 .065 Exp. Date $2 / 12 / 00$ QA $/ / \omega / 0 / 19 / 99$

Calibration No. Exp. Date QA

4.4.2 Transmation current (milliamp) simulator or equivalent Calibration No. $817.13-20-031$ Exp. Date 3-31.00 QA \&Q Calibration No. Exp. Date QA

4.4.3 Manometer (capable of a minimum of 5 inches water gauge to a maximum of 20 inches water gauge for this ATP) must have a read out of variable test pressure.

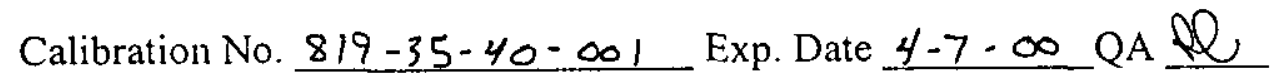

Calibration No. Exp. Date QA

4.4.4 Megaohm meter, at least 500vac range.

Calibration No. 681-45.45.001 Exp. Date 2/16/00 QA KW 10/19/99

4.4.5 6re $480 \mathrm{vac}, 3$ phase, 30 -ampere power source for PIC skid.

4.4.6 Selector switches (2 each) with at least one NO and one NC contact.

4.4.7 30. Proximity switches (for simulating LS-1 and LS-2), 2 each.

4.4.8 154. Leak detector probes (2 each), (Not required to be green tagged.) or 2 OK/OFF switches can be used to simulate leak detectors.

PAGE A-3 


\subsection{PRESTART CONDITIONS}

4.5.1 BAY Fill the water tank at least one-third to half full of water.

4.5.2 Ensure the PIC skid is grounded in preparation for ATP testing.

4.5.3 Ensure the following PIC skid valves in the WFIE cabinet are OPEN prior to starting this ATP.

BOA SALW-V-6035L (EQUALIZING)
BAy SALW-V-6036L (EQUALIZING)

4.5.4 Ensure the following PIC skid valves are CLOSED prior to starting this ATP.

Air Compressor cabinet:

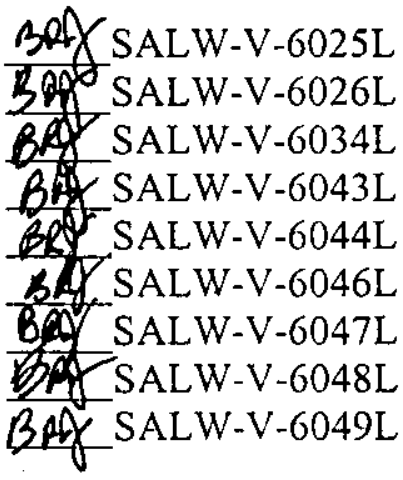

WFIE Cabinet:

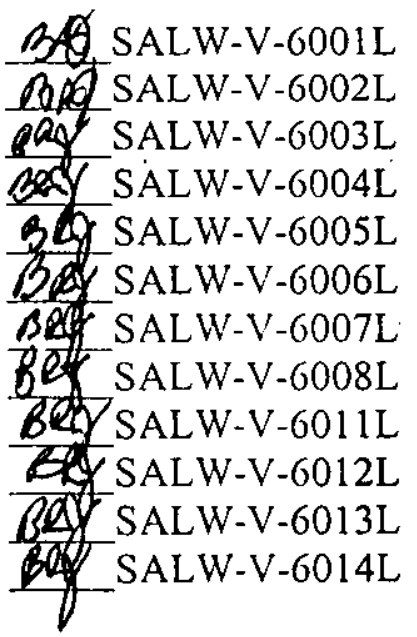

Water cabinet:

B2f SALW-V-6027L

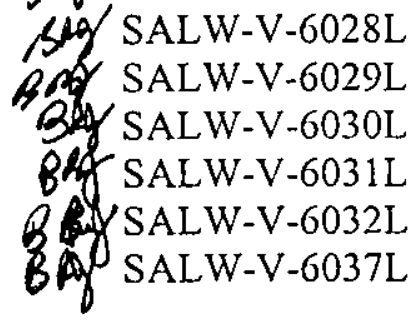

PAGE A-4 
4.5.5 Ensure the following PIC skid circuit disconnects, breakers and fuses are OPEN or OFF prior to starting this ATP.

$\frac{\text { 8RY SALW-DS-6002L BRY SALW-DS-6003L BRg SALW-DS- }}{6004 \mathrm{~L}}$ B\&SSALW-DS-6005L

The following breakers are in distribution panel SALW-DP-6001L:
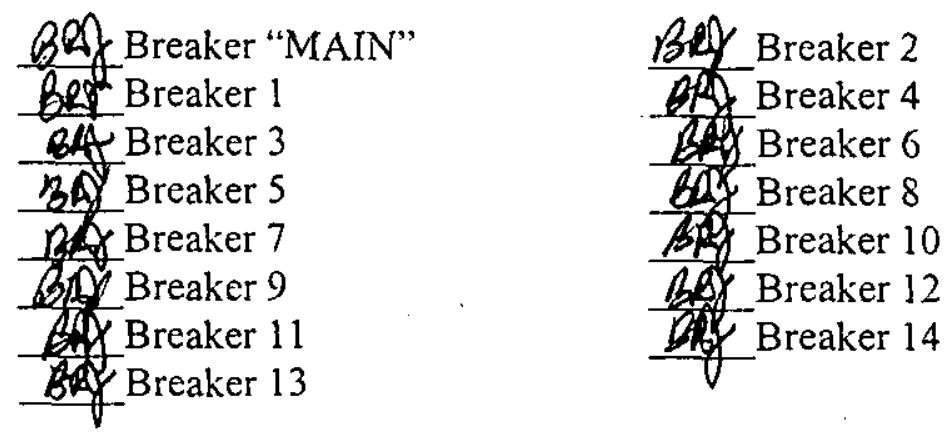

The following fuses are inside the Instrument Enclosure:

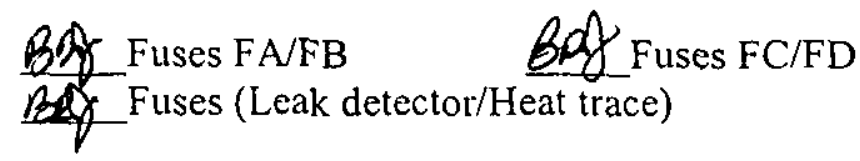

4.5.6 Check for lose electrical connections at the following locations:

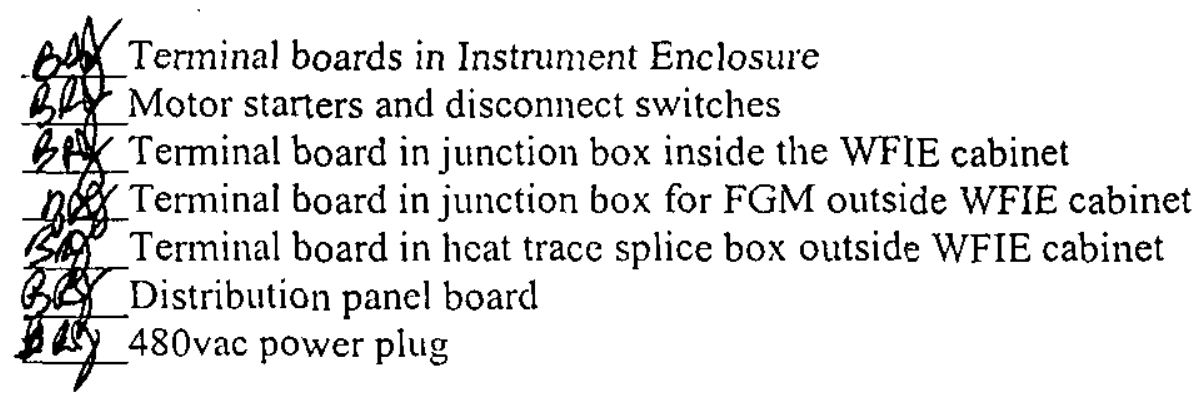

4.5.7 Bef Ensure desiccant and filters are installed in the air compressor dryer and the before and after filters. No desiccantition 2

4.5.8 Bey All personnel initialing and/or signing this pracedure shall enter their signature and initials on the Procedure Performer Signature Sheet on the last page of this document.

4.5.9 BR A pre-job safety meeting has been held before starting section 5.0 of tis ATP.

PAGE A-5 


\subsection{PROCEDURE}

\subsection{CONTINUITY CHECKS}

Continuity checks shall be performed with a calibrated VOM. Perform the checks as identified below. Readings are to be less than $1 \mathrm{ohm}$. Record ohms reading on the line(s) provided. Out of tolerance readings must be corrected and rechecked prior to going to the next section. NOTE: NEC inspection must be completed prior to proceeding.

5.1.1 480vac main power plug to line side of main disconnect switch (SALWDS-6002L). Check all three phases and ground.

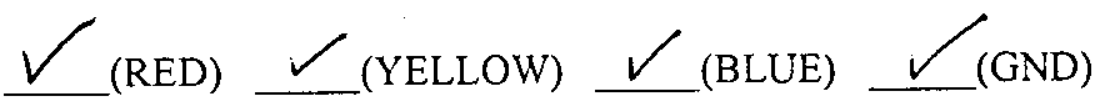

5.1.2 Load side of main disconnect switch (SALW-DS-6002L) to line side of transformer disconnect switch (SALW-DŞ-6003L). Check all three

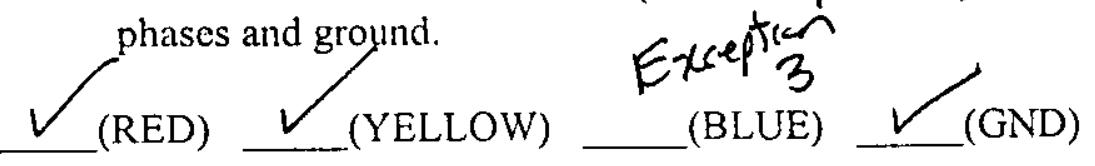

5.1.3 Load side of main disconnect switch (SALW-DS-6002L) to line side of jet pump motor starter (SALW-DS-6005L). Check all three phases and ground.

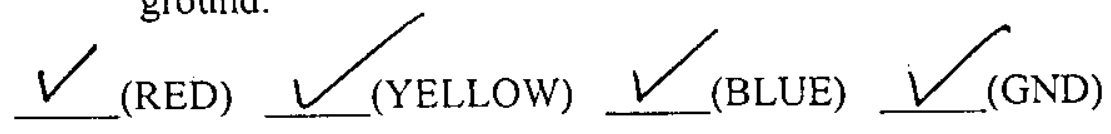

5.1.4 Load side of main disconnect switch (SALW-DS-6002L) to line side of air compressor motor starter (SALW-DS-6004L). Check all three phases and ground.

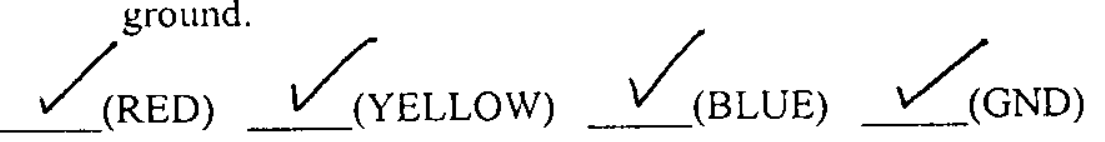

5.1.5 Load side of transformer disconnect switch (SALW-DS-6003L) through primary of transformer (SALW-XFMR-6001L). Check between the twophese wires going to the transformer.

(continuity through transformer primary) 


\section{REVISION 0}

5.1.6 Line side of main breaker in panel board (SALW-DP-6001L) through secondary of transformer (SALW-XFMR-6001L). Check between the two phases and between each phase and neutral going to the transformer secondary.

(Phase-A to phase-C, continuity through transformer secondary)

(Phase-A to neutral, continuity through transformer secondary)

(Phase-C to neutral, continuity through transformer secondary)

5.1.7 Load side of breakers in distribution panel (SALW-DP-6001L) to terminal point identified:

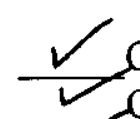

Circuit 3 to TB10 in Instrument Enclosure

Circuit 5 to TB13 in Instrument Enclosure

Circuit 12 to Air Conditioner/Heater receptacle in Instrument

Enclosure

Circuit 6 to safe side terminal board in Intrinsic Safe Panel

Circuit 1 to terminal board in FGM power junction box

$\checkmark$ Circuit 11 to terminal board in FGM power junction box

$\checkmark$ Circuit 13 to terminal board in FGM power junction box

$\checkmark$ Circuit 14 to terminal board in FGM power junction box

$\checkmark$ Circuit 2 to terminal board in FGM heat trace splice box

Circuit 10 to terminal board in FGM heat trace splice box

$\checkmark$ Circuit 4 to receptacle in air compressor cabinet

$\checkmark$ Circuit 7 to receptacles in WFIE cabinet

$\checkmark$ Circuit 8 to receptacle in Water cabinet

$\checkmark$ Circuit 9 to outside receptacle below panel board

Section 5.1 completed and all recorded readings within tolerance.

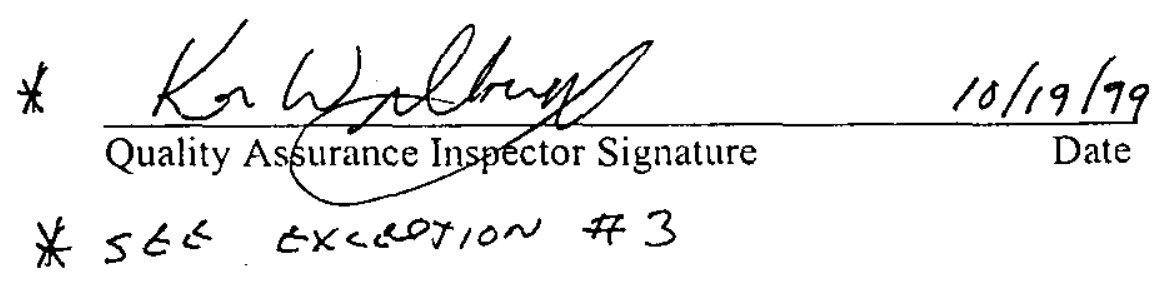

PAGE A-7 


\subsection{MEGGERING OF POWER WIRES}

The power wires shall be checked for resistance to ground and phase to phase. A 500volt megger shall be used for this check. Minimum acceptable readings expected are greater than 1000 megaohm or infinity. Test the circuits listed below. Record readings on the lines provided. Out of tolerance readings must be corrected and rechecked before going to the next section.

5.2.1 Each of the three phases at the pins of the power plug to ground and phase to phase. (Ensure main disconnect SALW-DS-6002L is OPEN.)

A-GND $\infty$; B-GND $\infty$; $\mathrm{C}-\mathrm{GND} \infty$; A-B $\infty$; A-C $\infty$; B-C $\infty$

5.2.2 Each of the three phases at the load side of the main disconnect switch (SALW-DS-6002L) to ground and phase to phase. (Ensure switches SALW-DS-6003L, SALW-DS-6004L and SALW-DS-6005L are OPEN.) A-GND $\infty ; \mathrm{B}-\mathrm{GND} \infty ; \mathrm{C}-\mathrm{GND} \infty ; \mathrm{A}-\mathrm{B} \infty ; \mathrm{A}-\mathrm{C} \infty ; \mathrm{B}-\mathrm{C} \perp$ 5.2 .3 Each of the two phases on the load side of the transformer disconnect
switch (SALW-DS-6003L) to ground.

PAGE A-8 
5.2.9 Megger each of the 14 circuits from the wire disconnected at the load side of the breaker to ground in the distribution panel.

NOTE: Disconnect each wire from the load side of the breaker prior to performing the megger check. Reconnect after meggering.

CKT.\#1 to GND $\infty$; CKT.\#2 to GND $\infty ;$ CKT.\#3 to GND $\infty$; CKT.\#4 to GND $\infty ; \overline{\mathrm{CKT} . \# 5}$ to GND $\infty$; $\overline{\mathrm{CKT} . \# 6}$ to GND $\infty ; \overline{\mathrm{CKT} . \# 7}$ to

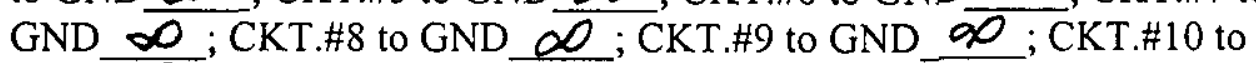
GND $\underline{\infty}$; CKT.\#11 to GND $\propto$; CKT.\#12 to GND $\infty$; CKT.\#13 to GND $\propto$; CKT.\#14 to GND $\infty$;

5.2.10 Ensure the load-side wire at each breaker is connected. 5.2.11 8 Reconnect the circuit-6-wire to the safe side terminal board at the

Section 5.2 completed and all recorded readings are within tolerance.

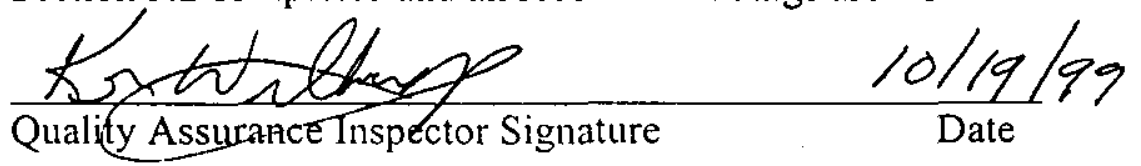

PAGE A-9 
RPP-5056

REVISION 0

\subsection{ELECTRICAL POWER CHECKS}

The voltage checks are to verify proper voltages throughout the skid at specific termination points. Voltages checked are $480 \mathrm{vac}, 3$ phase; 120vac, single phase; and $24 \mathrm{vdc}$. Out of tolerance readings must be corrected when found before going to the next step in this section.

5.3.1 Bfy Ensure that all electrical connections are completed. Wires lifted during the megger checks are to be reconnected.

5.3.2 Ensure all switches and breakers are open and the six fuses in the instrument cabinet are open.

5.3.3 BAy Ensure that all the fuses are in the two safety switches (SALW-DS6002L) (SALW-DS-6003L) and motor starters (SALW-DS-6004L) (SALW-DS-6005L) including the control transformers are installed.

5.3.4 BQf Connect the main power plug on the skid to a three phase, $480 \mathrm{vac}$ pover source. Source to be protected by no greater than 30 amperes over current protection.

5.3.5 Bef Tum ON the power source to the skid.

5.3.6 24 Verify $480 \mathrm{vac}+10 \mathrm{vac} / 20 \mathrm{vac}$ on the line side of the main disconnect switch (SALW-DS-6002L). Record the voltage.

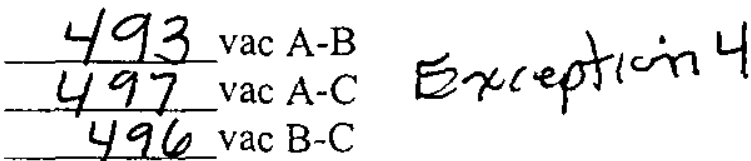

5.3.7 B Af Close the main disconnect switch (SALW-DS-6002L).

5.3.8 BA Verify $480 \mathrm{vac}+10 \mathrm{vac} / 20 \mathrm{vac}$ on the line side of the transformer disconnect switch (SALW-DS-6003L). Record the voltage.

493 vac A-C excepton' 4 5.3.9 BOY Verify $480 \mathrm{vac}+10 \mathrm{vac} /-20 \mathrm{vac}$ on the line side of the air compressor
molor starter (SALW-DS-6003L). Record the voltage. 492 vac $A-B$ 496 vac A-C 495 vac $B-C$

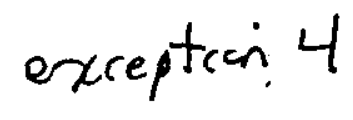

PAGE A-10 
5.3.10 BA Verify $480 \mathrm{vac}+10 \mathrm{vac} / 20 \mathrm{vac}$ on the line side of the pump motor starter (SALW-DS-6005L). Record the voltage. 492 vac A-B $\frac{496}{495}$ vac B-C exception 4

5.3.11 BAf Remove the dead front on the panel board (SALW-DP-6001L) for access to the main breaker for a voltage measurement.

5.3.12 Close the transformer disconnect switch (SALW-DS-6003L).

5.3.13 10 Check for $240 \mathrm{vac}+10 /-20$ at the line side of the main breaker. Record voltage. 246 vac

5.3.14 B. Open the transformer disconnect switch (SALW-DS-6003L).

5.3.15 Replace the dead front on the panel board (SALW-DP-6001L).

5.3.16 B COC Close the transformer disconnect switch (SALW-DS-6003L).

5.3.17 $\frac{B A \text { Close the } 100 \text { ampere main breaker in the panel board (SALW-DP- }}{600 \mathrm{~L} \text { ). }}$

PAGE A-1 1 
5.3.18_Check voltages for circuits at the following locations. Record the voltage reading on the space provided.

\begin{tabular}{|c|c|c|c|c|}
\hline CKT \# & $\begin{array}{c}\text { CHECK VOLTAGE } \\
\text { AT }\end{array}$ & $\begin{array}{l}\text { BKR OPEN } \\
\text { VOLTAGE } \\
\text { (NEAR 0vac) }\end{array}$ & $\begin{array}{l}\text { BKR CLOSED } \\
\text { VOLTAGE } \\
\text { (120+/-10vac) }\end{array}$ & $\begin{array}{c}\text { OPEN } \\
\text { BKR }\end{array}$ \\
\hline 1 & FGM J-BOX & 0 & 123 & $\checkmark$ \\
\hline 2 & FGM HT BOX & 0 & 123 & \\
\hline 3 & TB10, INSTR PNL & 0 & 122 & \\
\hline 4 & RCPT, AIR COMP & 0 & 122 & 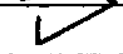 \\
\hline 5 & TB13, INSTR PNL & 0 & 122 & 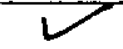 \\
\hline 6 & TB, INTRINSIC PNL & 0 & 122 & 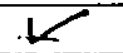 \\
\hline 7 & RCPT, WFIE & 0 & 122 & \\
\hline$\overline{8}$ & RCPT, WATER CAB & 0 & 122 & 2 \\
\hline$\overline{9}$ & OUTSIDE RCPT. & 0 & 122 & $V$ \\
\hline 10 & FGM HT BOX & 0 & 123 & $\checkmark$ \\
\hline 11 & FGM J-BOX & 0 & 123 & $\checkmark$ \\
\hline 12 & RCPT, INSTR PNL & 0 & 123 & $\checkmark$ \\
\hline 13 & $\overline{\text { FGM J-BOX }}$ & 0 & 123 & $\checkmark$ \\
\hline 14 & FGM J-BOX & 0 & 123 & \\
\hline
\end{tabular}

5.3.19 Install fuses FA, FB, FC and FD and close fuseholder.

5.3.20 B4 Install fuses and close heat trace/leak detector fuseholder. Close ckt 5 Bef $10 / 19199$

5.3.21 BD/Verify 120vac $+/$-10vac at the following fuseholder load side locations.

$\mathrm{FA} 122 ; \mathrm{FB} 122 ; \mathrm{FC} 122 ; \mathrm{FD} 122 ;$

close clet 3 BRg $1 0 / 1 9 \longdiv { 9 9 }$

Heat trace fuse(wire CKT $3 \mathrm{H}-\mathrm{B}) 122$;

Leak Detector fuse(wire CKT3H-A) 122

5.3.22 BA Verify $24 \mathrm{vdc}+/-2 \mathrm{vdc}$ at each $24 \mathrm{vdc}$ power supply.

First power supply 24,11 ; second power supply 24,10 Open ckt 3 and 5 BRf $18 / 19 / 99$

5.3.23 B 8 Open the 100 ampere main breaker in the panel board (SALW-DP$6001 \mathrm{~L}$ ).

5.3.24 BQY Open the transformer disconnect switch (SALW-DS-6003L).

5.3.25 BRYOpen the main disconnect switch (SALW-DS-6002L).

PAGE A-12 
Voltage checks completed satisfactorily.

I * Kon L

\subsection{SKID ELECTRICAL POWER UP}

During the following sections for instrument calibration and PLC/DTAM programming, electrical power will be required to the skid. The following sequence can be used to power up and power down the skid. Record breakers closed or opened in table below. Only circuits required to be powered need to be closed.

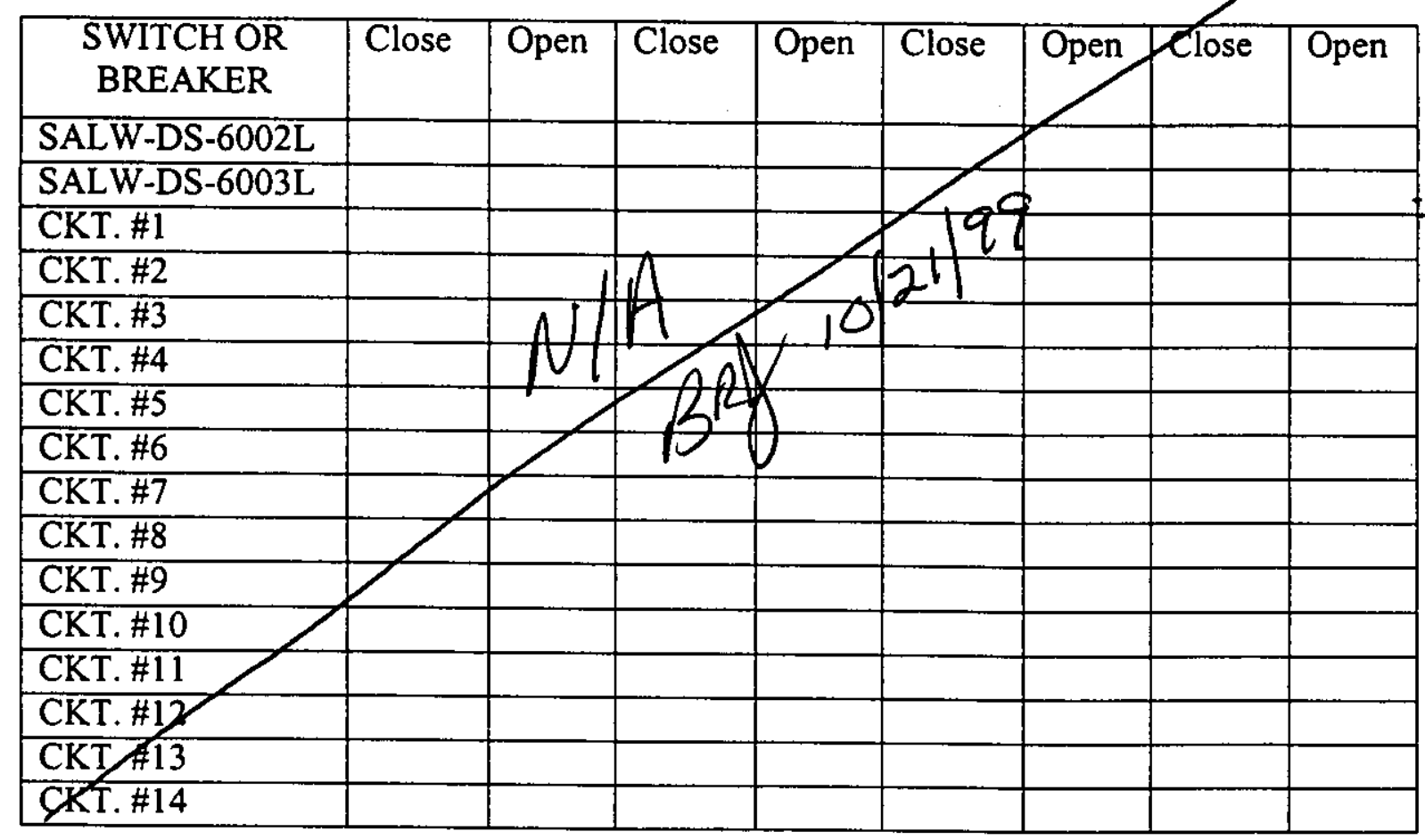

PAGE A-13 
RPP-5056

REVISION 0

\subsection{CALIBRATIONS}

Instrumentation equipment on the skid requires calibration prior to the functional testing. Lockheed Martin procedures will be used for this calibration. The table below identifies the equipment requiring calibration and the procedure for performing the calibration.

\begin{tabular}{l|ll}
\multicolumn{1}{c|}{ INSTRUMENT } & \multicolumn{1}{|c}{ LOCATION } & \multicolumn{1}{c}{ PROCEDURE } \\
\hline SALW-PS-6004L & INSTRU. AIR CAB. & 6-PCD-508 \\
SALW-WFT-6002L & WFIE CABINET & 6-PCD-361 \\
SALW-LT-6003L & WATER CABINET & 6-PCD-361 \\
SALW-SGT-6001L & WFIE CABINET & 6-PCD-361 \\
SALW-CONV-6001L & WFIE CABINET & 6-CVT-520 \\
SALW-FQIT-6001L & INSTRUMENT CAB. & Data sheet \& Vendor Man. \\
SALW-PI-6006L & AIR COMPRS. CABINET & 6-TF-509 \\
SALW-PI-6001L & WFIE CABINET & 6-TF-509 \\
SALW-PI-6005L & WFIE CABINET & 6-TF-509 \\
SALW-PI-6002L & WFIE CABINET & 6-TF-509 \\
SALW-PI-6003L & WFIE CABINET & 6-TF-509 \\
SALW-PI-6004L & WFIE CABINET & 6-TF-509 \\
SALW-PI-6007L & AIR COMPRS. CABINET & 6-TF-509 \\
SALW-PI-6008L & WATER CABINET & 6-TF-509 \\
\hline
\end{tabular}

Calibrations completed. Work package no. $w 5-99-1380,-1381,-1382,-7383$

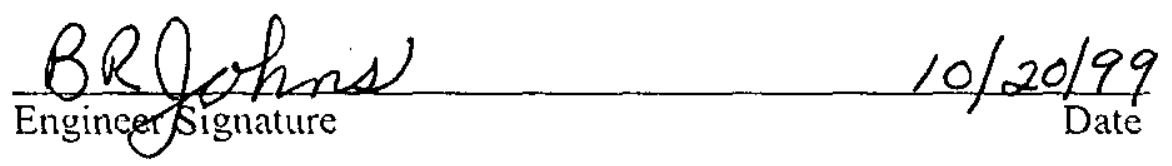

\subsection{PLC/DTAM PROGRAMMING}

This section is where the programs for the PLC and DTAM will be entered. Power will be required at the instrument cabinet to power up the PLC and DTAM. Power will also be required to the GFCI receptacle for power to the laptop computer. Lockheed Martin Interim Stabilization engineering will perform the programming of the PLC and DTAM. The final software programs shall be documented as required by HNF-3828, section 3.4. This documentation is not part of this ATP, but will be tracked by the Acceptance for Beneficial Use (ABU) document.

PLC/DTAM programmed.

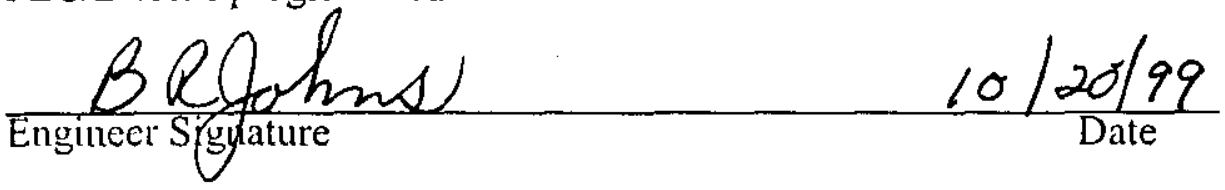




\subsection{SKID ELECTRICAL AND PROCESS AIR POWER-UP See expeption 2}

NOTE: The Third Party Pressure Vessel inspection report must be received prior to proceeding with this section. Refer to section 4.2.

5.8.1 $\mathrm{mN}$ \ENSURE the skid and remote equipment are connected before proceeding with the functional testing.

5.8.2 $\mathrm{m}$ J ENERGIZE the Pumping and Instrumentation Control Skid by CLOSING the following DISCONNECT SWITCHES in the order found below:

\begin{tabular}{|l|c|}
\hline \multicolumn{1}{|c|}{ DISCONNECT SWITCH } & $\begin{array}{c}\text { ENERGIZED } \\
(\checkmark)\end{array}$ \\
\hline SALW-DS-6002L & $\checkmark$ \\
\hline SALW-DS-6003L & $\checkmark$ \\
\hline SALW-DS-6004L & $\checkmark$ \\
\hline SALW-DS-6005L & $\checkmark$ \\
\hline
\end{tabular}

PAGE A-15 
RPP-5056

REVISION 0

5.8.3 MN JNERGIZE the Pumping and Instrumentation Control Skid by

CLOSING the following Circuit Breakers located in SALW-DP-6001L "SALW SKID DIST PNL" in the order found below:

\begin{tabular}{|l|c|}
\hline \multicolumn{1}{|c|}{ DISCONNECT SWITCH } & $\begin{array}{c}\text { ENERGIZED } \\
(\checkmark)\end{array}$ \\
\hline "MAIN" & $\checkmark$ \\
\hline 1, FGM AND HEATER (SPARE) & $\checkmark$ \\
\hline 3, HEAT TRACE \& LEAK DETECTION IN \\
INSTRUMENT ENCLOSURE
\end{tabular}

PAGE A-16 
RPP-5056

REVISION 0

5.8.4 $\mathrm{WN}^{\mathrm{S}}$ ACKNOWLEDGE any initial skid alarms.

5.8.5 $\mathrm{mN}$ J OPEN valve SALW-V-6034L (located in the Air COMP Cabinet).

5.8.6 $\mathrm{mNJ}$ START air compressor SALW-CMP-6001L "SALW SKID IA COMP" by POSITIONING switch on the SALW-DS-6004L to the ON position.

5.8.7 $\mathrm{WN}$ VERIFY that Air Compressor starts and builds up pressure AND shuts off at 86 to 94 psig, as indicated by pressure gauge SALW-PI-6006L (AIR DRYER INLET PRESS). Record shut off pressure: $90 \quad$ psig

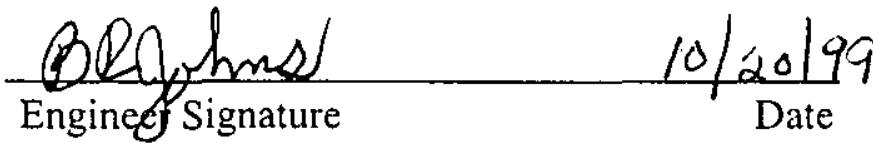

5.8.8 CHECK the tubing in the instrument air cabinet using a soap and water test to visually identify any air leaks. Repair as necessary. Deenergize the compressor motor and bleed off air as necessary to make repairs.

5.8.9 MNJ BLEED off air by slowly opening valve SALW-V-6043L until the compressor restarts, then close the valve and note the restart pressure.

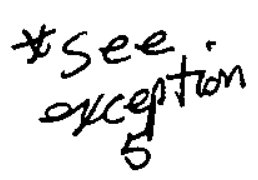

5.8.10 BRIVERIFY the air compressor restarts upon low pressure of 58 to 62 psig. Record pressure: $20^{\star}$ psig

5.8.11 WW VALVE in air to the PIC Skid Water Tank by SLOWLY PERFORMING the following (Refer to H-14-103543 Sheet 1):

5.8.12 CHECK for air leaks as each remaining step in this section is performed. Make repairs as necessary. Deenergize compressor motor and bleed off air pressure if necessary to make the repairs.

5.8.13 $\mathrm{mJJ}$ SLOWI.Y OPEN valve SALW-V-6025L located in the air compressor cabinet.

5.8.14 MaJ SLOWLY OPEN valve SALW-V-6027L (located near the water tank).

$5.8 .15 \frac{\mathrm{mN} \text { SLOWLY OPEN valve SALW-V-6028L (located near the water }}{\operatorname{tank} \text { ). }}$

PAGE A-17 
5.8.16 $\mathrm{MJ}$ ADJUST Pressure Regulator Valve SALW-PCV-6006L to $30 \mathrm{psi}$ $( \pm 3$ psig) as indicated by pressure gauge SALW-PI-6008L (WTR TK PRESS).

5.8.17 M VALVE IN air to WFIE Cabinet by PERFORMING the following (Refer to H-14-103543 Sheet 1):

5.8.18 MNJSLOWLY OPEN valve SALW-V-6026L located in the Air Compressor Cabinet.

5.8.19 MSLOWLY OPEN valve SALW-V-6001L, located in the bottom of WFIE Cabinet. (NOTE: SALW-PRV-6002L may open if pressure through SALW-PCV-6001L is too high.)

5.8.20 MD ADJUST pressure control valve SALW-PCV-6001L in WFIE Cabinet to $20 \mathrm{psi}( \pm 2.5 \mathrm{psi})$ as indicated by the pressure gauge located on the face of the valve.

5.8.21 $\mathrm{MN}$ SLOWLY OPEN valve SALW-V-6004L, located in the middle of WFIE Cabinet.

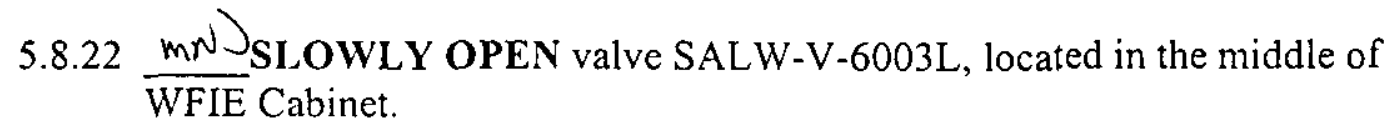

CAUTION: The next three steps cause air to flow from ports on outside of WFIE cabinet. 5.8.23 $\frac{\mathrm{WJ}}{\text { of WFIE Cabinet. }}$ SLOWLY OPEN valve SALW-V-6005L, located in the bottom left
of

5.8.24
of WFIE Cabinet.

5.8.25 mN JLOWLY OPEN valve SALW-V-6007L, located in the bottom left of WFIE Cabinet.

$5.8 .26 \frac{\mathrm{m} D}{\mathrm{~N}}$ SLOWLY OPEN valve SALW-V-6020L, located in the middle left
of WFIE Cabinet.

5.8.27 MN J SLOWLY OPEN valve SALW-V-6021L, located in the middle left of WFIE Cabinet.

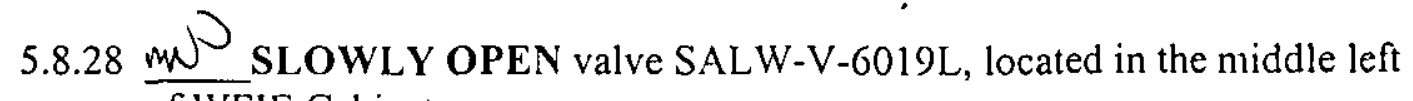
of WFIE Cabinet.

PAGE A-18 
5.8.29 ma J ADJUST the air flow through the diptubes by PERFORMING the following:

5.8.30 maDADJUS flow to dip tubes to $1.5 \mathrm{CFH}( \pm 0.5 \mathrm{CFH})$ as indicated by SALW-FIV-6002L.

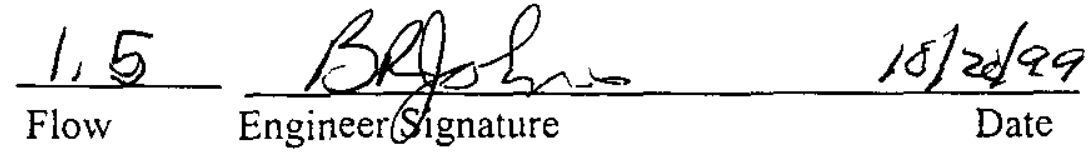

5.8.31 ma ADJUST flow to dip tubes to $1.5 \mathrm{CFH}( \pm 0.5 \mathrm{CFH})$ as indicated by SALW-FIV-6003L.

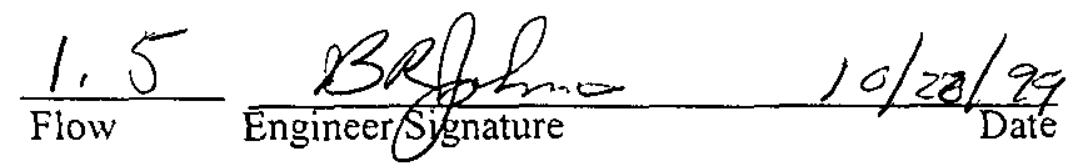

5.8.32 mu ADJUST flow to dip tubes to $1.5 \mathrm{CFH}( \pm 0.5 \mathrm{CFH})$ as indicated by SALW-FIV-6004L.

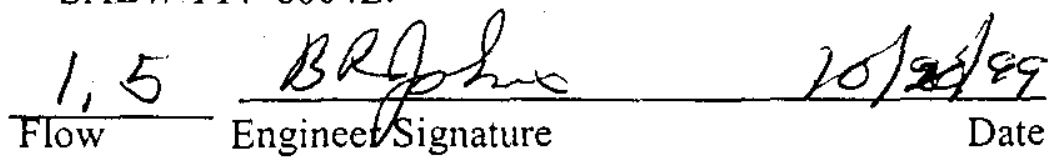

5.8.33 $\mathrm{MND}$ VALVE IN SALW-WFT-6002L AND SALW-SGT-6001L by PERFORMING the following:

5.8.34 MD ENSURE the LOW side AND HIGH side isolation valves, located on SALW-V-6036L in cabinet WFIE Cabinet are OPEN.

5.8.35 WW ENSURE SALW-WFT-6002L EQUALIZING valve on valve manifold SALW-V-6036L in cabinet WFIE Cabinet is CLOSED.

5.8.36 ma ENSURE the LOW side AND the HIGH side isolation valves, located on SALW-V-6035L in cabinet WFIE Cabinet are OPEN.

5.8.37 heN ENSURE SALW-SGT-6001L equalizing valve on valve manifold SALW-V-6035L in cabinet WFIE Cabinet is CLOSED.

5.8.38 $\mathrm{MN}$ CONFIRM that a signal is present between WFIE Cabinet instruments and the Programmable Logic Controller by PERFORMING the following: 
5.8.39 MNJ VERIFY Weight Factor is approximately 0.0" ( $\left.\pm 0.5^{\prime \prime}\right)$ Water Gauge as indicated by Data Table Access Module. If DTAM displays " $<<<"$ indicating less than zero, verify continuity between the transmitter and the Programmable Logic Controller and proceed with the test.

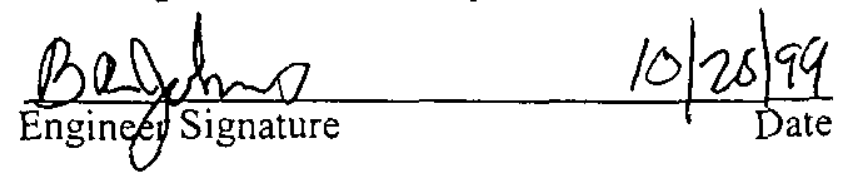

5.8.41 MNJVERIFY Specific Gravity is approximately $0.0^{\prime \prime}\left( \pm 0.5^{\prime \prime}\right)$ Water Gauge as indicated by Data Table Access Module. If DTAM displays " $\ll<<"$ indicating less than zero, verify continuity between the transmitter and the Programmable Logic Controller and proceed with the test.

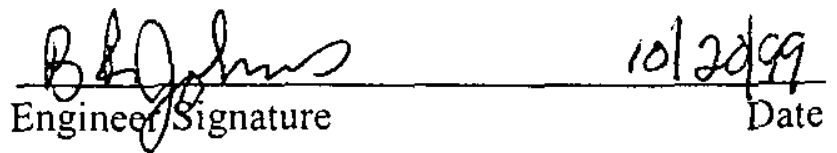

5.8.42 MNJ OPEN valve SALW-V-6035L Equalizing.

5.8.43 $\mathrm{m}_{N} \mathrm{~J}$ CLOSE valves SALW-V-6035L HI and LO.

5.8.44 Mul OPEN valve SALW-V-6036L Equalizing.

5.8.45 MNJCLOSE valves SALW-V-6036L HI and LO.

5.8.46 $\frac{\mathrm{WW}}{6020 \mathrm{~L}}$ CLOSE valves SALW-V-6019L, SALW-V-6021L and SALW-V-

5.8.47 MNJ VERIFY all air leaks repaired.

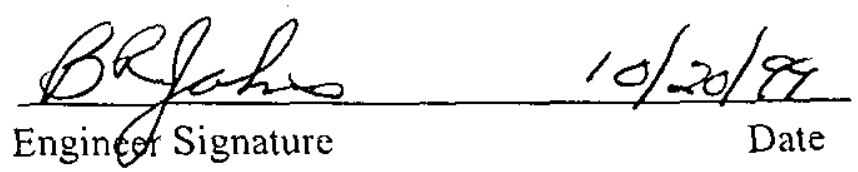

PAGE A-20 


\section{REVISION 0}

5.8.48 Engineer to VERIFY that section 5.8 is complete by SIGNING below.

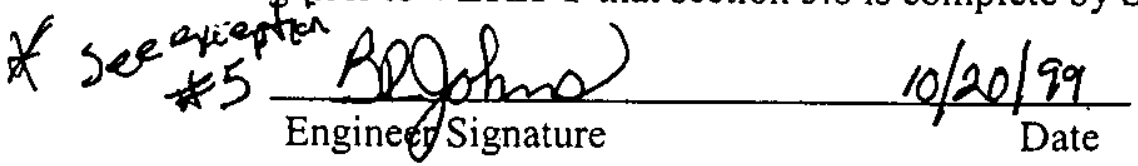

5.8.49 Quality Assurance Inspector to VERIFY that section 5.8 is complete by signing below.

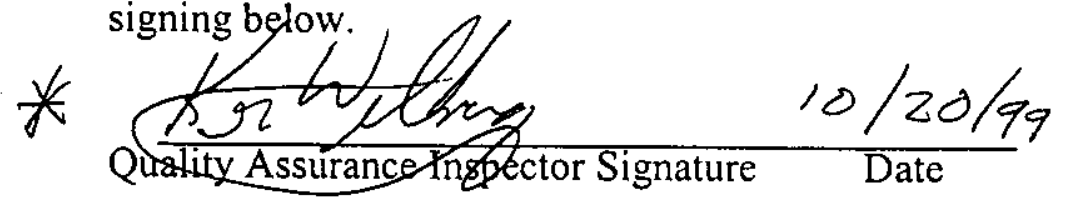

PAGE A-21 
RPP-5056

REVISION 0

\subsection{SKID WATER DRIP SYSTEM}

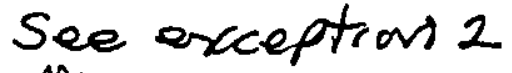

5.9.1 bef Provide a container to capture water expelled from the dip tubes and pressure relief valve SALW-PRV-6001L on the outside of the WFIE cabinet.

5.9.2 WJ ACTUATE the Dip Tube Drip system by SLOWLY OPENING the following valves:

\begin{tabular}{|l|c|}
\hline \multicolumn{1}{|c|}{ VALVES } & $\begin{array}{c}\text { OPEN } \\
(\checkmark)\end{array}$ \\
\hline $\begin{array}{l}\text { SALW-V-6016L } \\
\text { located in the middle of WFIE Cabinet }\end{array}$ & $\checkmark$ \\
\hline $\begin{array}{l}\text { SALW-V-6013L } \\
\text { located in the middle of WFIE Cabinet }\end{array}$ & $\checkmark$ \\
\hline $\begin{array}{l}\text { SALW-V-6008L } \\
\text { located in the middle of WFIE Cabinet }\end{array}$ & $\checkmark$ \\
\hline
\end{tabular}

\section{CAUTION}

Relief valve (SALW-PRV-6001L) will actuate and relieve pressure at 25 psig.

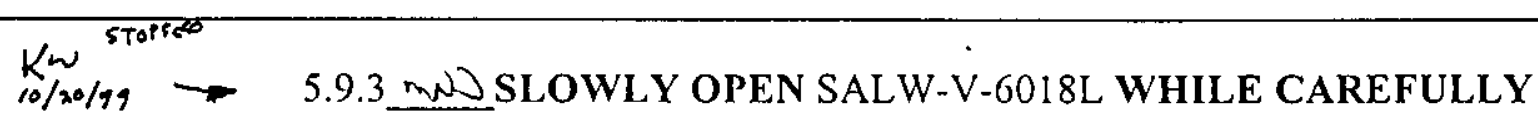

ADJUSTING Pressure Regulator SALW-PCV-6005L, located in the bottom of WFIE Cabinet to $20 \mathrm{psig}$ ( $\pm 2 \mathrm{psig}$ ) as indicated by

SALW-PI-6001L in the middle of WFIE Cabinet.

5.9.4 MNJADJUST valve SALW-V-6014L to allow APPROXIMATELY 2 drops/second as indicated by sight glass SALW-FG-6001L $( \pm 1$ drop/second).

5.9.5 WJ ADJUST valve SALW-V-6015L to allow APPROXIMATELY 2 drops/second as indicated by sight glass SALW-FG-6002) $( \pm 1$ drop/second). 

5.9.6PR VALVE OUT the dip tube drip water by SLOWLY CLOSING the
following:

\begin{tabular}{|l|c|}
\hline \multicolumn{1}{|c|}{ VALVE } & $\begin{array}{c}\text { CLOSED } \\
\text { ( })\end{array}$ \\
\hline $\begin{array}{l}\text { SALW-V-6015L } \\
\text { located in the middle of WFIE Cabinet }\end{array}$ & \\
\hline $\begin{array}{l}\text { SALW-V-6014L } \\
\text { located in the middle of WFIE Cabinet }\end{array}$ & \\
\hline $\begin{array}{l}\text { SALW-V-6008L } \\
\text { located in the middle of WFIE Cabinet }\end{array}$ & \\
\hline $\begin{array}{l}\text { SALW-V-6013L } \\
\text { located in the middle of WFIE Cabinet }\end{array}$ & \\
\hline
\end{tabular}

5.9.7 $\frac{\checkmark}{\mathrm{N} J}$ Ensure equalizing valve SALW-V-6035L is OPEN.

5.9.8 $\frac{\checkmark}{\mathrm{mNJ}}$ Ensure $\mathrm{HI}$ and LO isolation valves on SALW-V-6035L are CLOSED.

5.9.9 $\checkmark$ Ensure equalizing valve SALW-V-6036L is OPEN.

5.9.10 Ensure $\mathrm{HI}$ and LO isolation valves on SALW-V-6036L are CLOSED.

5.9.11 WWD Ensure the following valves in the order listed: SALW-V-6019L, SALW-V-6021L, SALW-V-6020L, SALW-V-6007L, SALW-V-6006L, and SALW-V-6005L are CLOSED.

5.9.12 m SLOWLY open valve SALW-V-6044L in the Air Compressor Cabinet.

5.9.13 MNDVerify air flows from pressure regulator SALW-PCV-6007L outside Air Compressor Cabinet.

5.9.14 mNJ CLOSE valve SALW-V-6044L in the Air Compressor Cabinet.

$5.9 .15 \mathrm{mD}$ SLOWLY open valve SALW-V-6048L in Air Compressor Cabinet.

5.9.16 $\frac{\mathrm{wN}}{\mathrm{ou}}$ Verify air flows from pressure regulator SALW-PCV-6008L outside Air Compressor Cabinet.

5.9.17 mW CLOSE valve SALW-V-6048L in the Air Compressor Cabinet. 
5.9.18 ma XLOWLY crack open valve SALW-V-6046L in the Air

Compressor Cabinet to VERIFY air flow at the fitting for the AOV, then RECLOSE SALW-V-6046L.

5.9.19 MNJ SLOWL $\dot{Y}$ crack open valves SALW-V-6047L and SALW-V$\overline{6046 \mathrm{~L}}$ in the Air Compressor Cabinet to VERIFY air flow at the drain line.

5.9.20 $\mathrm{WW}$ CLOSE valves SALW-V-6047L and SALW-V-6046L in the Air Compressor Cabinet.

5.9.21 $\mathrm{mNJ}$ SLOWLY crack open valve SALW-V-6043L in the Air Compressor Cabinet to VERIFY air flow at the tank drain line.

5.9.22 mMCLOSE valve SALW-V-6043L in the Air Compressor Cabinet.

5.9.23 Engineer to VERIFY that section 5.9 is complete by SIGNING below.

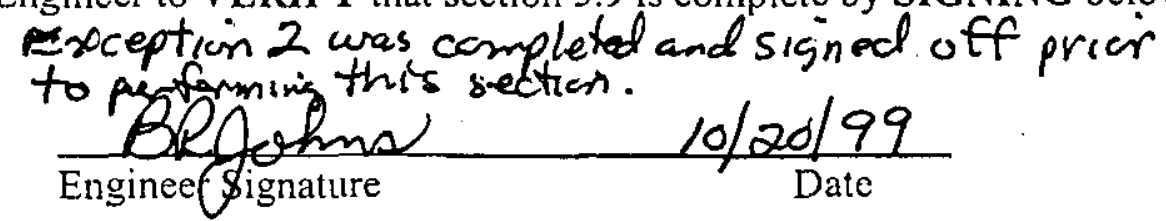

5.9.24 Quality Assurance Inspector to VERIFY that section 5.9 is complete by signing below.

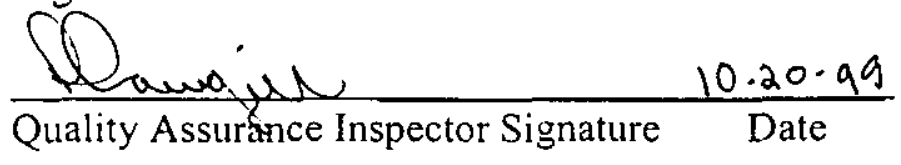

PAGE A-24 


\subsection{ANALOG INPUT SIGNALS TO THE PLC AND DTAM}

\section{Water Tank Level Transmitter}

5.10.1 MNJ PREPARE the Water Tank Level Transmitter SALW-LT-6003L for test signals by PERFORMING the following:

5.10.2 MN J ENSURE valve SALW-V-6029L, located in the bottom of WATER TANK ENCL, is CLOSED.

5.10.3 $\mathrm{mN}$ J ENSURE valve SALW-V-6031L, located in the bottom of WATER TANK ENCL, is CLOSED.

5.10.4 $\mathrm{mN}_{\mathrm{N}}$ CONNECT 0-62" test Manometer pressure source to the HIGH PRESSURE vent/test port of the level transmitter SALW-LT-6003L.

5.10.5 MN VERIFY the LOW PRESSURE vent/test port of the level transmitter SALW-LT-6003L is OPEN to atmosphere.

5.10.6 MNJ ADJUST the test Manometer on the SALW-LT-6003L to a pressure of $31^{\prime \prime}$ Water Gauge $( \pm 1 ")$.

5.10.7 MNRECORD the following:

\section{DATA TABLE ACCESS MODULE WATER TANK LEVEL (RANGE: 28.5 TO 33.5 Inches)}

31.1 inches

NOTE - In the next step, the alarm should annunciate between 11.75" and $12.75^{\prime \prime}$ Water Gauge.

$5.10 .8 \mathrm{~m} N \mathrm{~J}$ VERY SLOWLY DECREASE the Level Transmitter test Manometer pressure UNTIL the Data Table Access Module "PIC WATER LEVEL LOW" alarm (alarm 9) arnunciates.

5.10.9 mMN ACKNOWLEDGE the Water Tank Low Level alarm at the Data Table Access Module.

PAGE A-25 
5.10.10_ OBSERVE the Data Table Access Module AND RECORD the water tank level readings below:

\begin{tabular}{|c|}
\hline DATA TABLE ACCESS MODULE \\
WATER TANK LEVEL \\
(RANGE 11.75 to 12.75 inches Water Gauge) \\
12.2 inches \\
\hline
\end{tabular}

5.10.11 med SLOWLY INCREASE the Level Transmitter test Manometer pressure to $15.5^{\prime \prime}$ Water Gauge.

5.10 .12 OBSERVE the Data Table Access Module AND RECORD the water tank level readings below:

\section{DATA TABLE ACCESS MODULE WATER TANK LEVEL (RANGE 14.5 to 16.5 inches)}

$$
15.5 \text { in } 2405
$$

5.10.13 MNVRIFY "PIC WATER" is back to "norm" on DTAM.

5.10.14W REMOVE the test manometer from the SALW-LT-6003L high pressure vent/test port, AND RE-INSTALL vent plugs.

5.10.15 ${ }_{\text {mW }}$ RESTORE the Water Tank Level Transmitter SALW-LT-6003L by PERFORMING the following:

5.10.16 1 MN OPEN valve SALW-V-6029L, located in the bottom of WATER 5.10 .17 OPEN valve SALW-V-6031L, located in the bottom of WATER TANK ENCL.

5.10.18 1 WN VERIFY "WATER TANK" on DTAM shows a value in inches.

\section{PAGE A-26}




\section{WEIGHT FACTOR TEST}

5.10.19 ${ }^{\text {mn }}$ VERIFY that NO Programmable Logic Controller input signals are FORCED and that the forcing function is DISABLED.

5.10.20 ${ }^{\mathrm{WW}}$ CONNECT the 0-500" Water Gauge test Manometer pressure source to the HIGH PRESSURE dip tube on the side of the "WFIE Cabinet."

5.10.21 ENSURE SALW-V-6001L is CLOSED.

5.10.22 - ENSURE SALW-V-6005L is OPEN.

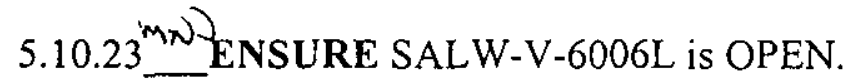

5.10.24 mN ENSURE adjustment valves on SALW-FIV-6002L, SALW-FIV-

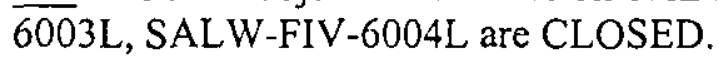

5.10.25 WN ENSURE SALW-WFT-6002L EQUALIZING valve located on SALW-V-6036L 3-Valve Manifold in cabinet WFIE Cabinet is CLOSED.

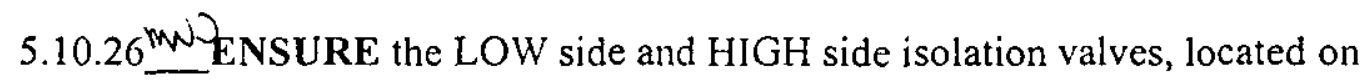
SALW-V-6036L 3-Valve Manifold in cabinet WFIE Cabinet are OPEN.

5.10.27 3 SET the test Manometer to 125" Water Gauge.

5.10.28 MNOBSERVE Data Table Access Module AND RECORD the Weight Factor on the table below.

\begin{tabular}{|c|c|}
\hline $\begin{array}{c}\text { DATA TABLE ACCESS MODULE } \\
\text { WEIGHT FACTOR READING } \\
\text { (RANGE 120 to 130 inches) }\end{array}$ \\
125.2 inches \\
\hline
\end{tabular}

5.10 .29 MN BLEED off pressure from the manometer.

5.10 .30 wW CLOSE SALW-V-6006L.

5.10.31 WW DPEN SALW-WFT-6002L equalizing valve, located on

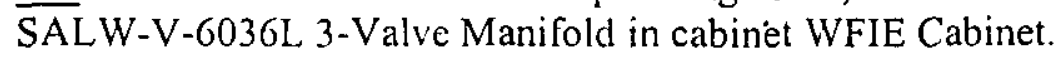

5.10.32 $2_{\text {W }}$ CLOSE the LOW side and HIGH side isolation valves, located on SALW-V-6036L 3-Valve Manifold in cabinet WFIE Cabinet.

PAGE A-27 


\section{SPECIFIC GRAVITY TEST}

$5.10 .33^{m \text { DJ }}$ ENSURE SALW-V-6007L is OPEN.

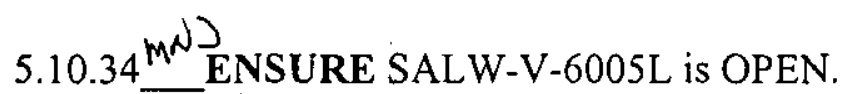

5.10 .35 ENSURE the LOW side and the HIGH side isolation valves, located on SALW-V-6035L in cabinet WFIE Cabinet are OPEN.

$5.10 .36^{m+1}$ CLOSE the Specific Gravity Transmitter equalizing valve located on SALW-V-6035L in cabinet WFIE Cabinet.

5.10.37 NSET the test Manometer to 5" Water Gauge ( $\pm .3 ")$.

5.10.38 m DBSERVE Data Table Access Module AND RECORD the Specific Gravity reading on the table below.

\section{DATA TABLE ACCESS MODULE \\ SPECIFIC GRAVITY READING \\ (RANGE 4.65 to 5.35 inches)}

$$
5.08 \text { inches }
$$

$5.10 .39^{\text {mw }}$ BLEED off pressure from the manometer.

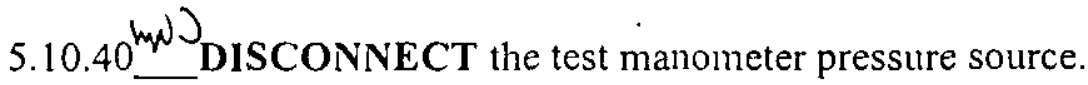

5.10.41 $1^{\mathrm{W} J}$ CLOSE SALW-V-6007L.

5.10.42 $2^{\mathrm{WWJ}}$ CLOSE SALW-V-6005L.

5.10 .43 MND OPEN SALW-SGT-6001L cqualizing valve, located on SALW-V-6035L 3-Valve Manifold in cabinet WFIE Cabinet.

$5.10 .44 \mathrm{mu}^{\mathrm{N}}$ CLOSE the LOW side and HIGH side isolation valves, located on SALW-V-6035L 3-Valve Manifold in cabinet WFIE Cabinet.

\section{FLOW METER TEST}

5.10.45 $\mathrm{MM}$ IF necessary CONNECT the brain terminal to the SALW-FQIT-6001L (SUPERNATANT FLOW XMIT), located in cabinet Instrument Cabinet.

PAGE A-28 
5.10.46 MN ENSURE SALW-FQIT-6001L is powered and configured for simulated flow signals.

5.10 .47 SIMULATE a flow signal of $2.0 \mathrm{gpm}$ ( $50 \%$ span) with the hand held calibrator, or from flowmeter face plate.

5.10.48 1 VERIFY the SALW-FQIT-6001L transmitter is operating properly by $\overrightarrow{R E C O R D I N G}$ the following:

\begin{tabular}{|c|c|}
\hline $\begin{array}{c}\text { DATA TABLE ACCESS MODULE } \\
\text { SUPERNATANT FLOW } \\
\text { (RANGE: } 1.8 \text { TO 2.2 GPM) }\end{array}$ & $\begin{array}{c}\text { SUPERNATANT FLOW } \\
\text { XMIT } \\
\text { SUPERNATANT FLOW } \\
\text { (RANGE: 1.8 TO 2.2 GPM) }\end{array}$ \\
\hline $2.0 \mathrm{GPm}$ & 2.0 GPM - \\
\hline
\end{tabular}

5.10.49 WN RESTORE the SALW-FQIT-6001L (SUPERNATANT FLOW TRANSMITTER) to its original configuration.

\section{SUCTION AND DISCHARGE PRESSURE SIGNAL}

5.10.50 WW CONNECT a current source to PSPT+ and PSPT- at the intrinsic side terminal board in the Intrinsic Safe panel.

$5.10 .51 \frac{}{6012} \mathrm{~L}$ in the table below. Reading is to be approximately zero.

5.10 .52 SET the current source to $20 \mathrm{~mA}$ and record the suction pressure. in the table below. Reading is to be approximately 100psi. ind

DISCONNECT the current source.

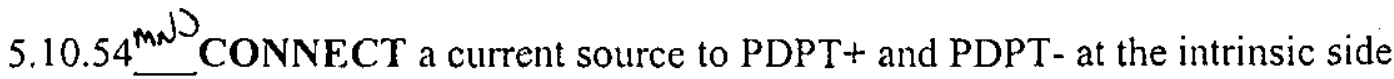
terminal board in the Intrinsic Safe panel.

$5.10 .55^{\mathrm{m} N \mathrm{~S}}$ SET the current to $4 \mathrm{~mA}$ and record the discharge pressures on SALWPI-6011L and on the DTAM in the table below. Readings are to be approximately zero.

PAGE A-29 
$5.10 .56{ }^{\mathrm{MN}}$ SET the current source to $20 \mathrm{~mA}$ and record the discharge pressures in the table below. Readings are to be approximately 300 psi.

$5.10 .57^{\text {m }} \mathrm{N}^{\mathrm{D}}$ DISCONNECT the current source.

5.10 .58 RECORD the following pressures on the table below:

\begin{tabular}{|c|c|c|c|c|}
\hline $\begin{array}{c}\text { SALW-PI-6012L } \\
\text { JET PUMP } \\
\text { SUCTION } \\
\text { PRESSURE }\end{array}$ & $\begin{array}{c}\text { DTAM } \\
\text { DISCHARGE } \\
\text { PRESSURE }\end{array}$ & $\begin{array}{c}\text { SALW-PI-6011L } \\
\text { JET PUMP } \\
\text { DISCHARGE } \\
\text { PRESSURE }\end{array}$ & \\
\hline 0.1 & At $4 \mathrm{~mA}$ & 0 & 0.3 & At 4mA \\
\hline 100.3 & At $20 \mathrm{~mA}$ & 300 & 299.9 & At $20 \mathrm{~mA}$ \\
\hline
\end{tabular}

\section{PIT FLAMMABLE GAS MONITOR ANALOG SIGNAL TO PLC}

5.10.59 $\mathrm{NN}$ CONNECT a current source to terminal board TB1 in the PICS Instrument Enclosure, points FGM $0(+)$ and FGM $0(-)$.

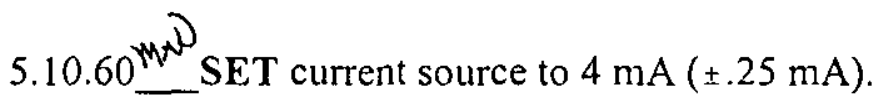

5.10.61 ${ }_{\text {RECORD the Data Table Access Module Flammable Gas DISPLAY }}$ on the "Pit FGM Input/Output Table" below. (Expected value to be approximately $0 \%$.)

5.10 .62 mas SET current source to $10 \mathrm{~mA}( \pm .25 \mathrm{~mA})$.

5.10.63 MNRECORD the Data Table Access Module Flammable Gas display on the "Pit FGM Input/Output Table" below. (Expected value to be approximately $11 \%$.)

$5.10 .64^{\mathrm{Aw}}$ SET current source to $20 \mathrm{~mA}( \pm .25 \mathrm{~mA})$.

PAGE A-30 
5.10.65 ${ }^{\mathrm{N}} \mathrm{J}_{\text {RECORD the Data Table Access Module Flammable Gas display on }}$ the "Pit FGM Input/Output Table" below. (Expected value to be approximately $30 \%$.)

\begin{tabular}{|c|c|}
\hline \multicolumn{2}{|c|}{ Pit FGM Input/Output Table } \\
\hline $\begin{array}{c}\text { Input } \\
(\mathrm{mA})\end{array}$ & $\begin{array}{c}\text { Output (as displayed on } \\
\text { Data Table Access Module) }\end{array}$ \\
\hline 4 & 0 \\
\hline 10 & 11.3 \\
\hline 20 & 30 \\
\hline
\end{tabular}

5.10.66 ${ }^{\mathrm{HO}}$ DISCONNECT the current source.

DOME SPACE FLAMMABLE GAS MONITOR ANALOG SIGNAL TO PLC

5.10.67 CONNECT a current source to terminal board TB1 in the PICS Instrument Enclosure, points FGM 1(+) and FGM 1(-).

$5.10 .68 \mathrm{mN}$ SET current source to $4 \mathrm{~mA}(+/-.25 \mathrm{~mA})$.

5.10.69 $\mathrm{MN}$ RECORD the Data Table Access Module Flammable Gas DISPLAY on the "Dome Space FGM Input/Output Table" below. (Expected value to be approximately $0 \%$.)

$5.10 .70 \stackrel{\mathrm{mN}}{ }$ SET current source to $10 \mathrm{~mA}( \pm .25 \mathrm{~mA})$.

5.10.7 1 MECORD the Data Table Access Module Flammable Gas display on the "Dome Space FGM Input/Output Table" below. (Expected value to be approximately $11 \%$.)

$5.10 .72 \mathrm{mWS}$ SET current source to $20 \mathrm{~mA}( \pm .25 \mathrm{~mA})$.

\section{PAGE A-31}


5.10.73 $3^{m D}$ RECORD the Data Table Access Module Flammable Gas display on the "Dome Space FGM Input/Output Table" below. (Expected value to be approximately $30 \%$.)

\begin{tabular}{|c|c|}
\hline \multicolumn{2}{|c|}{ Dome Space FGM Input/Output Table } \\
\hline $\begin{array}{c}\text { Input } \\
(\mathrm{mA})\end{array}$ & $\begin{array}{c}\text { Output (as displayed on } \\
\text { Data Table Access Module) }\end{array}$ \\
\hline 4 & 0 \\
\hline 10 & 11.3 \\
\hline 20 & 30 \\
\hline
\end{tabular}

5.10.74 DISCONNECT the current source.

\section{THERMOCOUPLE INPUTS TO PLC}

5.10.75 WNVIVARM thermocouple SALW-TE-6004L, located in the Instrument Enclosure.

5.10.76 1 WERIFY Data Table Access Module displays a changed temperature.

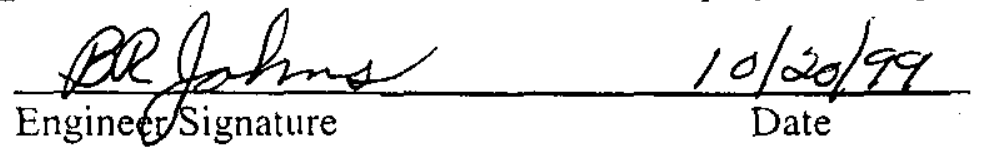

5.10.77 WERIFY SALW-TE-6004L temperature decreases after heat source removed.

5.10.78 $\mathrm{mW}$ JWARM thermocouple SALW-TE-6003L, located in INSTRUMENT AIR ENCLOSURE.

5.10.79 1 HERIFY Data Table Access Module displays a changed temperature.

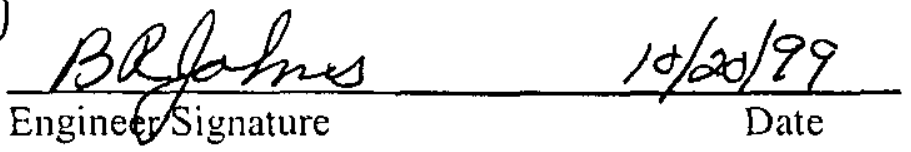

5.10 .80 WERIFY SALW-TE-6003L temperature decreases after heat source removed. 
5.10.81 1 CONNECT a thermocouple probe to the intrinsic side of top thermocouple module (MTL 3081) in the Intrinsic Safe Panel. (This will simulate pump temperature.)

5.10.82 WARM the connected thermocouple probe.

5.10.83 HERIFY Data Table Access Module displays a changed temperature.

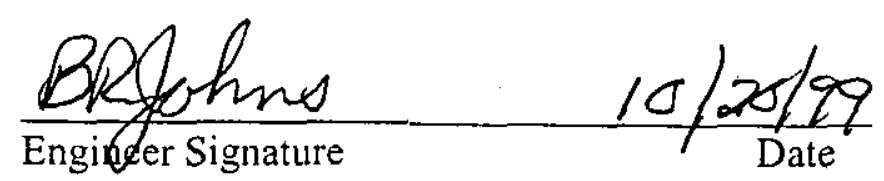

5.10.84 VERIFY the connected probe temperature decreases after heat source removed.

$5.10 .85^{m}$ DISCONNECT the temperature probe.

$5.10 .86 \mathrm{WN}$ CONNECT a thermocouple probe to the second thermocouple module in the Intrinsic Safe panel. (This will simulate jumper temperature.)

5.10 .87 WWARM the thermocouple probe.

5.10.88 WN WERIFY Data Table Access Module (screen 25)displays a changed temperature

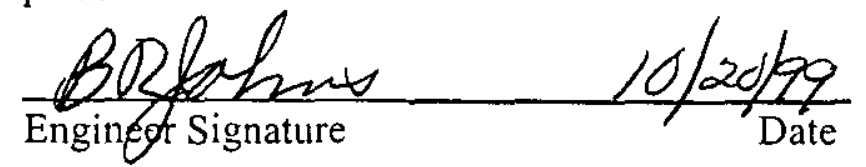

$5.10 .89 \frac{\text { WW }}{\text { removed. }}$ VERIFY SALW-TE-6002L temperature decreases after heat source

$5.10 .90 \mathrm{mN}$ DISCONNECT the temperature probe.

\section{RECIRCULATION FLUSH PRESSURE SIGNAL TO PLC}

5.10 .91 CONNECT a current source to points RFPT+ and RFPT- at the intrinsic side terminal board in the intrinsic Safe panel. (Set the current source to "TRANSMITTER SIMULATE."

$5.10 .92^{\text {hur }}$ SET the current source to $4 \mathrm{~mA}$.

$5.10 .93^{\text {man }}$ SLOWLY increase the current output until an alarm on the DTAM for High Recirc. Flush Pressure(alam 8 ) occurs. (Approx. 12.5mA.)

$$
39 \text { Beg } 10120199
$$




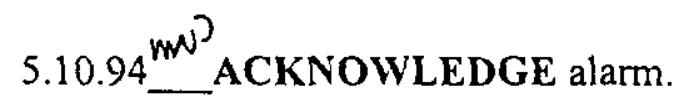

5.10 .95 VERIFY the pressure on the DTAM for RFPT is approximately $15 \mathrm{psi}$.

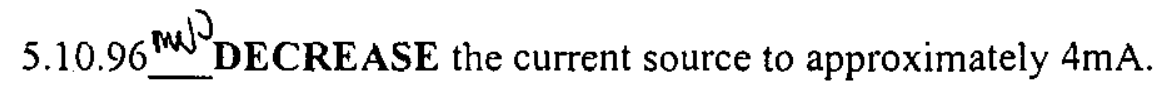

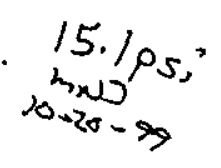

5.10 .97 VERIFY the High Recirc. Flush Pressure alarm clears on the DTAM.

5.10 .98 m D DISCONNECT the current source.

5.10.99 VERIFY a "RFPT SIGNAL LOSS" alarm (14) occurs.

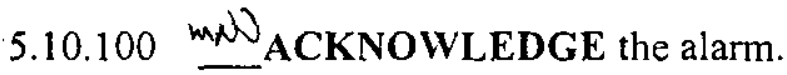

\section{JUMPER FLUSH PRESSURE SIGNAL TO PLC}

5.10.101 $\mathrm{ND}$ CONNECT a current source to points JFPT+ and JFPT - at theintrinsic side terminal board in the Intrinsic Safe panel.

5.10.102 $\mathrm{MN}$ SET the current source to $4 \mathrm{~mA}$.

5.10.103 WN SLOWLY increase the current output until an alarm on the DT $\overline{\mathrm{AM}}$ for High Flush Pressure(alarm 3) occurs and the BLUE light on the instrument panel is ON. (Approx. 12.5mA.)

5.10.104 $\mathrm{WN}^{\mathrm{J}}$ ACKNOWLEDGE alarm.

5.10.105 WDERIFY the pressure on the DTAM for JFPT is approximately 15 psi.

$5.10 .106 \mathrm{MN}$ DECREASE the current source to $4 \mathrm{~mA}$.

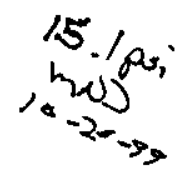

5.10.107 IWNJ VERIFY the High Flush Pressure alarm clears on the DTAM and the BLUE light turns OFF.

5.10 .108 DISCONNEC $T$ the current source.

5.10.109 WUP VERIFY a "JFPT SIGNAL LOSS" alarm (16) occurs.

$5.10 .110 \mathrm{md}$ ACKNOIVLEDGE the alarm.

PAGE A-34 
5.10.111 Engineer VERIFY that section 5.10 is complete by SIGNING below.

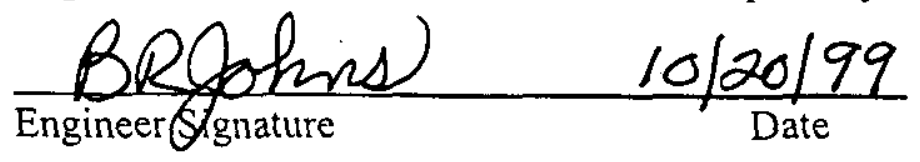

5.10.112 Quality Assurance Inspector VERIFY that section 5.10 is complete by signing below.

$\frac{\text { Lavweipe }}{\text { Quality Asstifance Inspector Signature }} \frac{10-20 \cdot 99}{\text { Date }}$

\subsection{DISCRETE SIGNAL INPUTS TO PLC AND DTAM}

NOTE: The DIP switches on the Intrinsic Safe Panel may require changing in order to get the proper responses for LS-1 and LS-2.

\section{JR-1 VALVE POSITION (LS-1/LS-2) INPUT}

5.11.1 $m_{y}$ D CONNECT a normally closed transducer across the LS-1+ and LS1 - and a normally open transducer across the LS-2+ AND LS-2- points on the intrinsic safe terminal board in the Intrinsic Safe panel.

5.11.2 WW ACTUATE both transducers by placing a piece of steel in front of the each transducer face.

5.11.3 VERIFY the JR-1 valve indicates "norm" at the Data Table Access Module.

5.11.4 $\mathrm{mN}$ REMOVE the metal from in front of the LS-1 switch installed in the above step.

5.11.5 VERIFY the JR-1 valve indicates "NON-PROCESS" at the Data Table Access Module and address N20:32/0 is actuated on ladder 5 (rung 89).

5.11.6 $\mathrm{m}$ J REMOVE the metal from in front of the LS-2 switch.

5.11.7 NDS VERIFY the JR-1 valve still indicates "NON-PROCESS" at the Data Table Access Module and address N20:32/1 is actuated on ladder 5 (rung 91).

5.11.8 $\mathrm{mv}^{د}$ REPLACE the metal in front of the LS-2 and the LS-1 transducers.

PAGE A-35 
5.11.9 $\mathrm{mw}$ VERIFY the JR-1 valve indicates " norm" at the Data Table Access Module and addresses N20:32/0 and N20:32/1 are clear on ladder 5 (rungs 89 and 91).

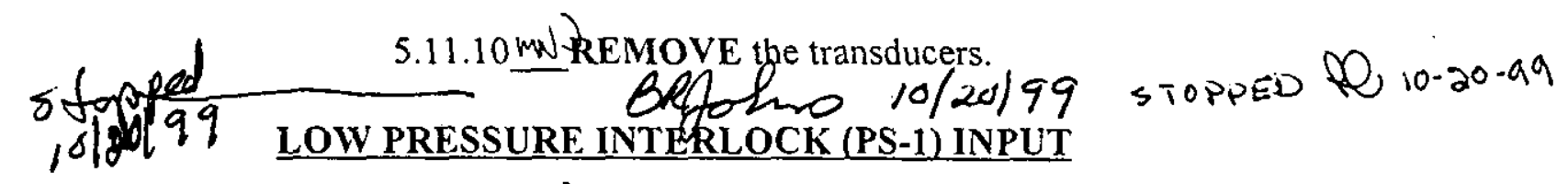

5.11.11 $\mathrm{mr}$ CONNECT a normally closed switch across points PS-1-NO and PS$\overline{1-1}(\mathrm{H})$ at the intrinsic safe terminal board in the Intrinsic Safe panel.

$5.11 .12^{m /}$ VERIFY the GREEN light on the instrument panel is ON.

$5.11 .13 w^{2}$ APPLY software forces to allow the pump to start. Exception 5.11 .14 TURn ON/OFF switch on joet pump starter to ON

5.11 .15 VERIFY the RED light on the instrument panel is $O N$ and the GREEN light is OFF.

$5.11 .16 \mathrm{mN}$ OPEN the PS- 1 switch.

5.11.17 MERIFY that the amber light on the instrument panel tums ON immediately after the switch is open.

5.11.18 ${ }^{m}$ VERIFY a "XFR Pressure LOW" alarm (alarm 1) occurs at the DTAM and a pump shutdown occurs indicated by the horn sounding, strobe flashing, shutdown alarm on the DTAM, the red light turning OFF, and the green light turning ON. ACKNOWLEDGE alarms at Data Table Access Module to verify the various alarms.

5.11 .19 mN CLOSE the PS-1 switch to clear the "XFR PRESSURE LOW" alarm and turn OFF amber light.

$5.11 .20^{\mathrm{m} N \mathrm{~N}}$ REMOVE the test switch.

5.11 .21 LEAVE the forces in place for the high pressure test.

\section{HIGH PRESSURE INTERLOCK (PS-1-1) INPUT}

5.11.22 $\mathrm{mx}$ CONNECT a normally closed switch at points PS-1-NC and PS-1$\mathrm{l}(\mathrm{H})$ at the intrinsic safe terminal board in the Intrinsic Safe panel.

5.11.23 MNPESS the pump start from DTAM.

5.11.24 MrDVRIFY the RED light on the instrument panel is $O N$ and the GREEN light is OFF.

PAGE A-36 
5.11.25nJ OPEN the switch across the PS-1-1 points.

5.11.26 my JVERIFY a "XFR Pressure HIGH" alarm (alarm 2) at the DTAM, and a pump shutdown occurs indicated by the horn sounding, strobe flashing, shutdown alarm on the DTAM, the red light turning OFF, and the green light turning $\mathrm{ON}$ after a 3 second delay. ACKNOWLEDGE the alarms at the DTAM to verify the various alarms.

$5.11 .27^{m+W}$ DISCONNECT the switch.

5.11 .28 REMOVE the software forces. as necessay 1012199

\section{DILUTION TANK NO FLOW INPUT}

$m N=$

5.11.24 PLACE a normally closed switch across terminal points DIL-F and CKT5H-A on terminal board TB4 in the Instrument Cabinet.

$\min$

5.11.25ERIFY no dilution tank no flow alarm on the DTAM (alarm 35, screen 135).

m

5.11.20 OPEN the switch at TB4.

5.11.27 $7^{\text {m }}$ VERIFY a dilution tank no flow alarm on the DTAM.

5.11.28 ${ }^{\mathrm{mN} \text { \} } \text { ACKNOWLEDGE the alarm. }$

$5.11 .29^{m}$ CLOSE the switch.

5.11 .30 met J VERIFY alarm clears.

5.11 .31 DISCONNECT the switch.

\section{FLAMMABLE GAS MONITOR INPUT}

$5.11 .32^{\text {mwJ }}$ CONNECT a normally closed switch to points FGM and CKT5H-A on terminal board TB 4 in the instrument cabinet.

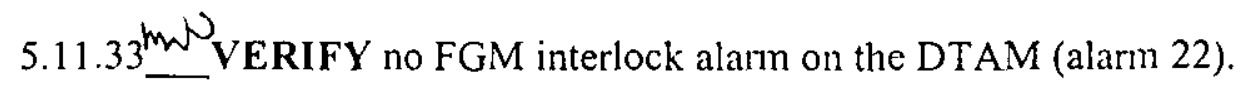

5.11 .34 mw) OPEN the switch.

$5.11 .35^{\mathrm{mn}}$ VERIFY an FGM alarm on the DTAM.

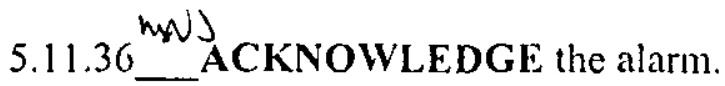

PAGE A-37 
5.11.37 $\stackrel{\mathrm{Wm}}{\mathrm{WLOSE}}$ the switch.

$5.11 .38^{m^{2}}$ VERIFY the FGM alarm clears.

5.11.39 ${ }^{\mathrm{m} N \mathrm{~J}}$ LEAVE the switch connected for the Heat Trace check.

\section{HEAT TRACE CONTROL FOR PUMP AND JUMPER}

5.11.40 1 VERIFY that heat trace relays HT-1 and.HT-2 are deenergized by checking for zero voltage across points 2 and 7 at each relay.

5.11.41 VERIFY zero voltage at TB12 between HT-1 and CKT3-N.

5.11.42 mU TUN ON heat trace from DTAM to actuate relays HT-1 and HT-2.

5.11.43 $3_{\mathrm{WWN}} \mathrm{CHECK}$ for $120 \mathrm{vac}$ at TB-12, points HT-1 and CKT3-N.

5.11.44 NOPEN the FGM switch.

5.11.45 VERIFY 0vac at TB-12, points HT-1 and CKT3-N.

5.11 .46 TURN OFF heat trace from the DTAM.

5.11 .47 MEMOVE the switch.

5.11.48Engineer VERIFY that section 5.11 is complete by SIGNING below. * See exieption 6

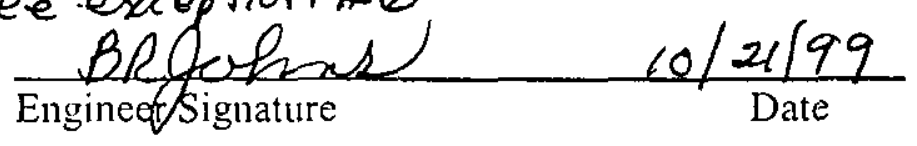

5.11.49Quality Assurance Inspector VERIFY that section 5.11 is complete by signing below.

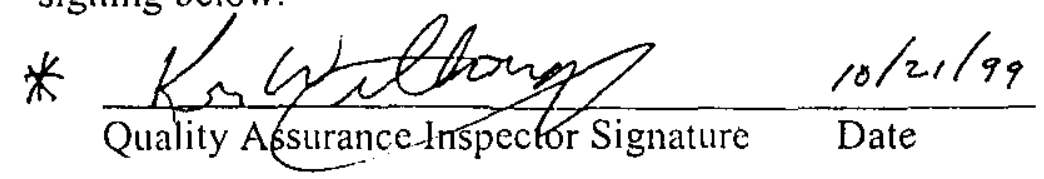




\subsection{HEATERS AND AIR CONDITIONER}

5.12.1 $m$ N JURN the heater ON in the air compressor cabinet. Set the thermostat high enough to allow the unit to operate.

5.12 .2

$m$ N.

RESET the thermostat to approximately 40 degrees $F$ to allow the unit to turn OFF.

5.12.3 wW TURN the fan thermostat switch low to allow the fan in the air compressor cabinet to run.

5.12.4 mWJ RESET the fan switch to approximately 90 degrees.

5.12.5 $\mathrm{MNJ}$ TURN the heater ON in the WFIE cabinet. Set the thermostat high enough to allow the unit to operate.

5.12.6 $\mathrm{WW}$ RESET the thermostat to approximately 40 degrees $F$ to allow the heater to tum OFF.

5.12.7 $\mathrm{mN}$ TURN the heater ON in the Water cabinet. Set the thermostat high enough to allow the unit to operate.

5.12.8 $\mathrm{mN}$ RESET the thermostat to approximately 40 degrees $F$ to allow the heater to tum OFF.

5.12.9 MNJ TURN the heater ON in the Instrument cabinet. Set the thermostat high enough to allow the unit to operate.

5.12.10 RESET the thermostat to approximately 40 degrees $F$ to allow the heater to turn OFF.

5.12 .11 TJ TUN ON the air conditioner in the Instrument cabinet. If necessary, remove the front grill on the unit and adjust the temperature setting lower to get the unit to operate.

5.12.12 RESET the tempcrature setting to approximately 90 to 95 degrees.

PAGE A-39 
5.12.13Engineer VERIFY that section 5.12 is complete by SIGNING below.

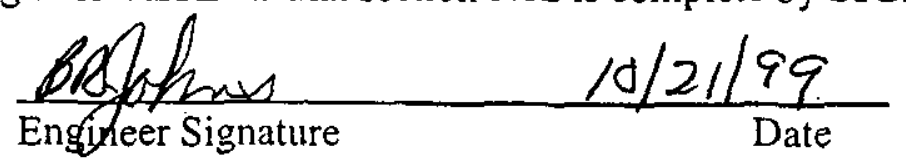

5.12.14Quality Assurance Inspector VERIFY that section 5.12 is complete by signing below.

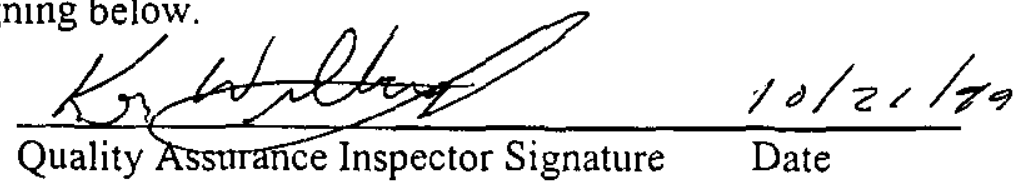

PAGE A-40 
RPP-5056

REVISION 0

\subsection{LEAK DETECTION INTERLOCK CHECK}

5.13.1 $\mathrm{mWJ}$ Set up two buckets for leak detector testing if leak detector probes are used for testing.

NOTE - A supply of water needs to be available to pour into the buckets during testing.

- $\quad$ Pump operation will be simulated during the remainder of the ATP.

\section{WARNING}

Energized circuits and leads are contained inside the cabinet. Observe appropriate electrical. Comply with HNF-PRO-088, ELECTRICAL WORK SAFETY to avoid personnel electrical shock hazards.

5.13.2 MN PERFORM or VERIFY performed the CGI dedication for the leak detector relays per HNF-4275 and WTF-1-18 and WTF-30-16.

5.13.3 MNCONNECT a leak detector probe to the primary leak detector terminals at TB11 in the Instrument Cabinet, points SD-1A, SD-1B, SA$1 \mathrm{~A}$, and $\mathrm{SA}-1 \mathrm{~B}$ and CONNECT a leak detector probe to leak detector $\# 1$ terminals at TB11 in the Instrument Cabinet, points SD-2A, SD-2B, SA2A, and SA-2B. IF NECESSARY remove the jumpers from the terminal block for leak detector \#1.

\section{OR}

WNJ

NA CONNECT a normally open switch to the primary leak detector terminals at TB11 in the Instrument Cabinet, points SD-1A, SD-1B, SA$1 \mathrm{~A}$, and SA-1B and CONNECT a normally open switch to leak detector \#1 terminals at TB11 in the Instrument Cabinet, points SD-2A, SD-2B, SA-2A, and SA-2B. (NOTE: Connect SD-LA and SA-LA wires to one pole of the switch and SD-LB and SA-LB wires to the other pole of the switch.) IF NECESSARY remove the jumpers from the terminal block for leak detector \#1.

5.13.4 $\frac{\mathrm{mN}^{\mathrm{N}}}{\text { and 7). }}$ VERIFY no primary leak detector alarms at the DTAM (alarms 6

5.13.5 $\mathrm{m} N \mathrm{DLACE}$ the primary leak detector assembly in a bucket of water or close the test switch on the primary leak detector.

PAGE A-41 
5.13.6 $\mathrm{mN}$ J VERIFY a leak detector leak and trouble alarm for the primary leak detector is received at the DTAM (alarm 6) after a 3 second delay.

5.13.7 MNJ ACKNOWLEDGE the Leak Detector Alarm at the Data Table Access Module.

5.13.8 $\mathrm{m}^{\mathrm{N}}$ REMOVE the leak detector assembly from the bucket and allow the water to drain off the assembly into the bucket or open the test switch.

5.13.9 WN VERIFY the leak detector alarms clear at the DTAM.

5.13 .10 DNISCONNECT one of the "SD" wires going to the probe or switch.

5.13 .11 VERIFY trouble alami 7 occurs.

5.13 .12 ACKNOWLEDGE the alarm.

5.13.13 VERIFY no leak detector \#1 alarms at the DTAM (alarms 18 and 19).

5.13 .14 PLACE the leak detector \#1 assembly in a bucket of water or close the switch for leak detector \#1.

5.13.15 VERIFY a leak detector leak and trouble alarm for leak detector \#1 is received at the DTAM.

5.13.16 ${ }^{m N}$ ACKNOWLEDGE the Leak Detector Alarm at the Data Table Access Module.

5.13.17 han REMOVE the leak detector assembly from the bucket and allow the water to drain off the assembly into the bucket or open the test sivitch.

5.13.18 1 VERIFY the leak detector alarms clear at the DTAM.

5.13.19 DISCONNECT one of the "SD" wires going to the probe or switch.

$5.13 .20 \stackrel{\mathrm{ma}}{\longrightarrow}$ VERIFY trouble alarm 19 occurs.

$5.13 .21^{\mathrm{mW} J}$ ACKNOWLEDGE the alarm.

5.13 .22 DISCONNECT the probes or switches from TB11.

5.13.23 ENSURE the jumpers for leak detector \#1 are installed at TB 11 .

PAGE A-42 
5.13.24 Engineer VERIFY that section 5.13 is complete by SIGNING below.

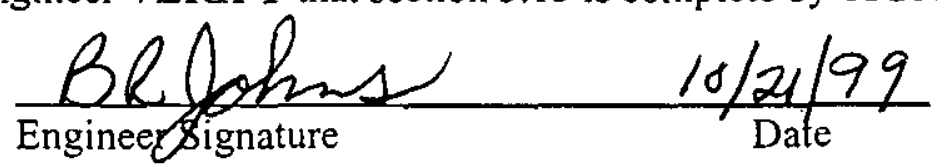

5.13.25 Quality Assurance Inspector VERIFY that section 5.13 is complete by signing below.

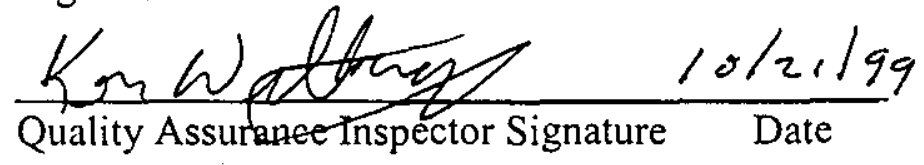


RPP-5056

REVISION 0

\subsection{SKID SHUTDOWN AFTER ATP}

5.14.1 Drain water from water tank in the Water Cabinet by opening valve SALW-V-6030L. Catch water in a container or route to an appropriate drain.

5.14.2 Ensure the following PIC skid valves in the WFIE cabinet are OPEN.

$\checkmark$ SALW-V-6035L (EQUALIZING)

$\checkmark$ SALW-V-6036L (EQUALIZING)

5.14.3 Ensure the following PIC skid valves are CLOSED.

Air Compressor cabinet:

Water cabinet:

\begin{tabular}{c}
$\checkmark$ SALW-V-6025L \\
\hline$\checkmark$ SALW-V-6026L \\
$\checkmark$ SALW-V-6034L \\
$\checkmark$ SALW-V-6043L \\
\hline$\checkmark$ SALW-V-6044L \\
\hline$\checkmark$ SALW-V-6046L \\
\hline$\checkmark$ SALW-V-6047L \\
\hline$\checkmark$ SALW-V-6048L \\
\hline$\checkmark$ SALW-V-6049L
\end{tabular}

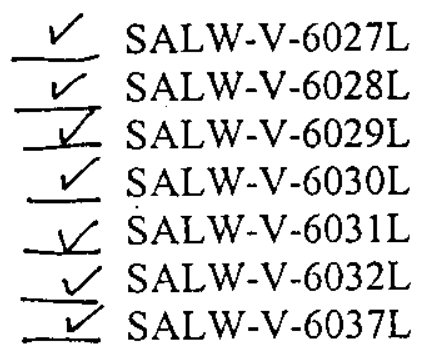

WFIE Cabinet:

$\checkmark$ SALW-V-6001L

$\checkmark$ SALW-V-6002L

$\checkmark$ SALW-V-6003L

$\checkmark$ SALW-V-6004L

$\checkmark$ SALW-V-6005L

$\checkmark$ SALW-V-6006L

$\checkmark$ SALW-V-6007L

$\checkmark$ SALW-V-6008L

$\checkmark$ SALW-V-6011L

$\checkmark$ SALW-V-6012L

$\checkmark$ SALW-V-6013L

$\checkmark$ SALW-V-6014L

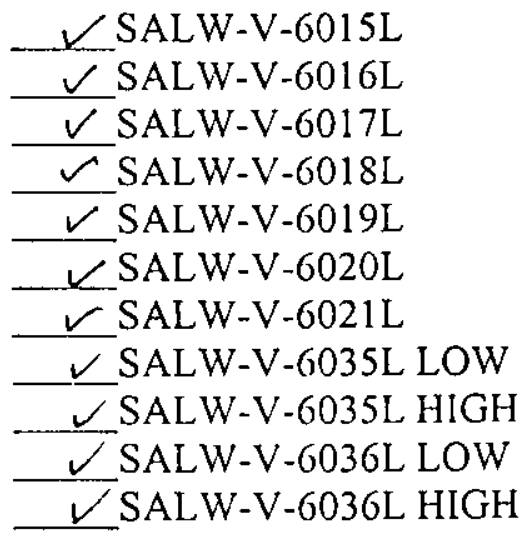

5.14.4 Ensure the following PIC skid circuit disconnects, breakers and fuses are OPEN or OFF.

$m$ J SALW-DS-6002L WN) SALW-DS-6003L mNJSALW-DS6004L mNJSALW-DS-6005L

PAGE A-44 
The following breakers are in distribution pancl SALW-DP-6001L:

\begin{tabular}{l}
$\checkmark$ Breaker "MAIN" \\
$\checkmark \checkmark$ Breaker 1 \\
$\checkmark$ Breaker 3 \\
$\checkmark$ Breaker 5 \\
\hline$\checkmark$ Breaker 7 \\
$\checkmark$ Breaker 9 \\
\hline$\checkmark$ Breaker 11 \\
$\square$ Breaker 13
\end{tabular}

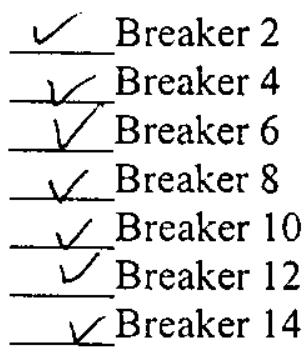

5.14.5 mW DISCONNECT the power plug from the 480vac power source.

5.14.6 BRSENSURE the power plug on the power cable is the correct model per A-14-103538, item 41.

5.14.7 Engineer VERIFY that section 5.14 is complete by SIGNING below.

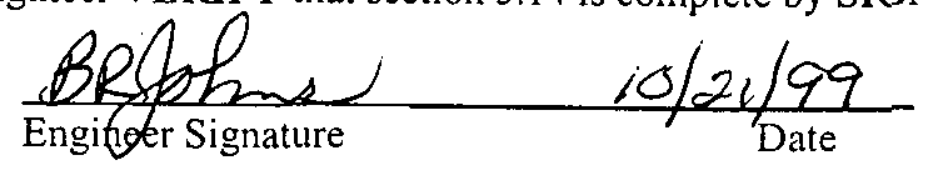

5.14.8 Quality Assurance Inspector VERIFY that section 5.14 is complete by signing below.

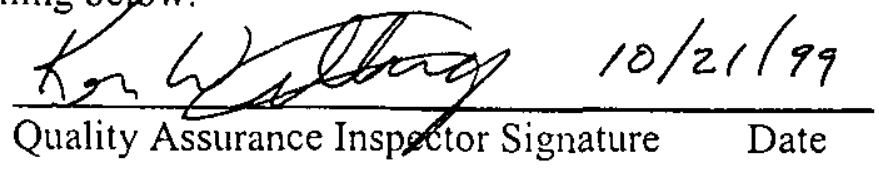


RPP-5056

REVISION 0

\subsection{REDLINE INCORPORATION}

5.15.1 VRERIFY the redlines identified in the redline log in the Fabrication work package are incorporated into the revised drawings for skid " $\mathrm{L}$ ".

NOTE: Redlines incorporation must meet the intent of the redline log. The redlines may not be exactly the same as marked on the working drawings. Example: If a part was added to a drawing and then it is discovered that the part already existed on the drawing, then the final incorporation may be to increase the quantity of the existing part. Drawing views may change from the redline version in order to meet drafting standards.

5.15.2 Engineer to VERIFY section 5.15 is completed by signing below.

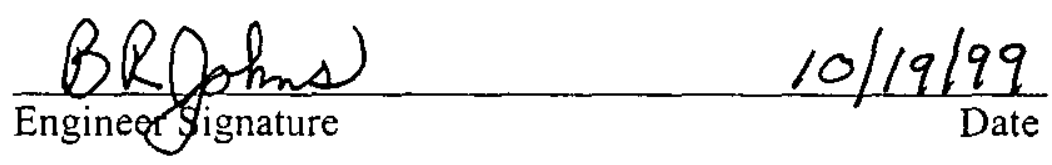

5.15.3 Quality Assurance Inspector to VERIFY section 5.15 is completed by signing below.

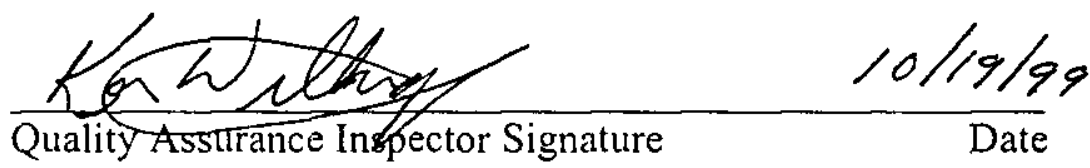


RPP-5056

REVISION 0

ACCEPTANCE TEST PROCEDURE

This page may be reproduced as necessary

PAGE of

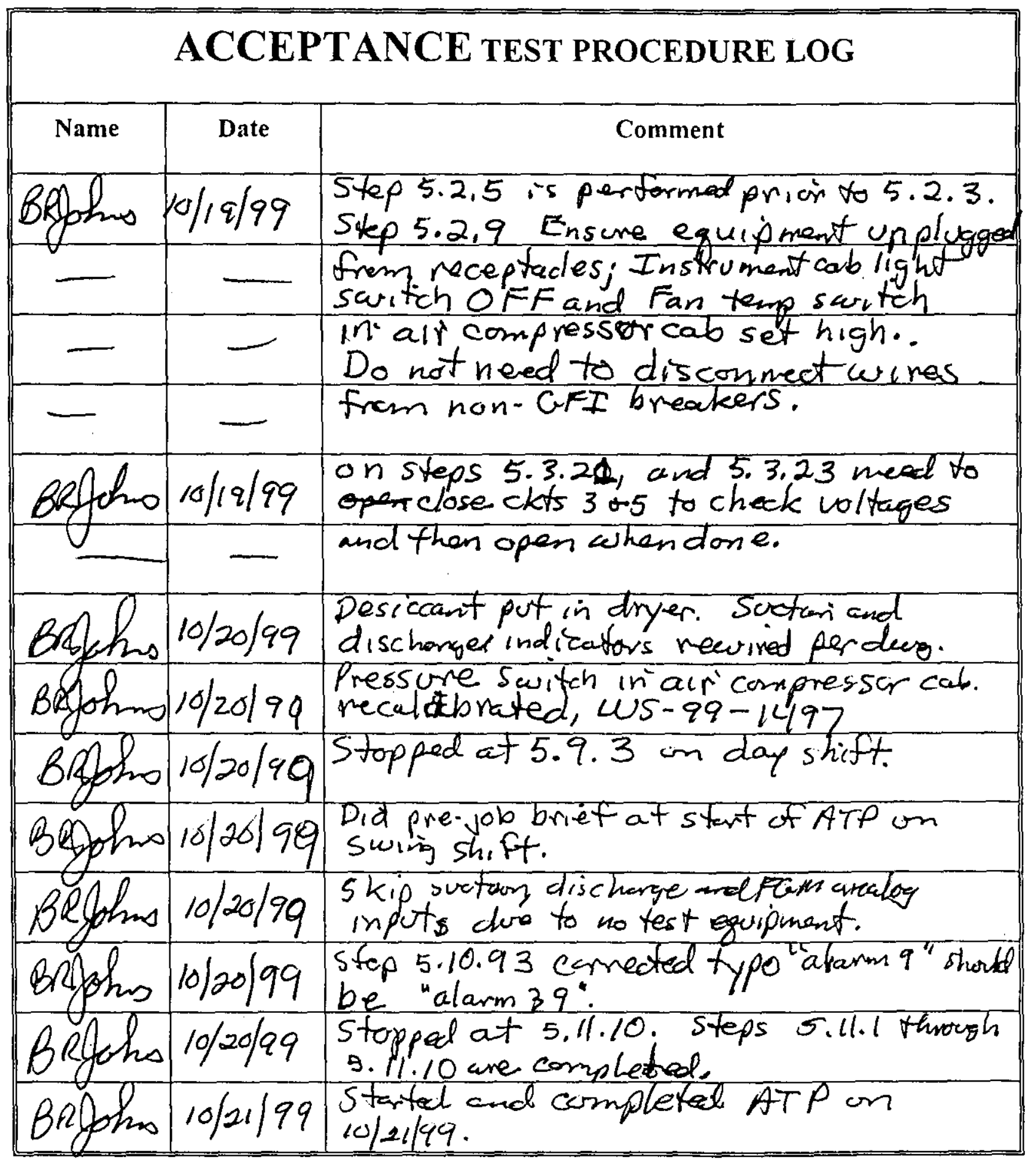

PAGE A-47

WORK ORDER $2 \mathrm{H} 9903386 \mathrm{~F}$

PAGE $123-54$ OF 


\section{ACCEPTANCE TEST PROCEDURE EXCEPTION LOG}

\begin{tabular}{|c|c|c|}
\hline Number & Date & Description \\
\hline I & $10 / 19 / 99$ & $\begin{array}{l}\text { H-14-103538 Sh+11. Wiring to } \\
\text { SALW-PI-60d/L and-PI-6012L hoconact. }\end{array}$ \\
\hline- & - & Not per drawing. \\
\hline 2 & $10 / 19 / 99$ & Step 4.5.7 Desiccant not in dryer. \\
\hline 3 & $10 / 19 / 99$ & Step 5.1 .2 Thind phase not comnded. \\
\hline 4 & $10 / 1969$ & $\begin{array}{l}\text { Steps } 5.3 .6,5.3 .8,5.3 .9+5.3 .10 \\
\text { the } 480 \text { vac readings are high. }\end{array}$ \\
\hline 5 & $1 0 / 2 0 \longdiv { 9 9 }$ & $\begin{array}{l}\text { Sfep } 5.8 .10 \text { Pressyd switch set pount } \\
\text { forcompressor restant too high. }\end{array}$ \\
\hline 6 & $10 / 21 / 99$ & $\begin{array}{l}\text { step } 5.1114 \text { Need Uet pump storter } \\
\text { switoh to oN }\end{array}$ \\
\hline & & \\
\hline & & \\
\hline & & \\
\hline & & \\
\hline & & \\
\hline & & \\
\hline & & \\
\hline ( & 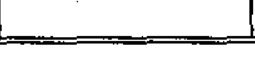 & 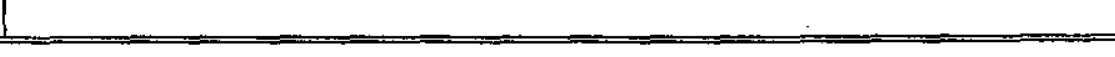 \\
\hline
\end{tabular}

PAGE A-48 


\section{ACCEPTANCE TEST PROCEDURE EXCEPTION RECORD}

This page may be reproduced as necessary.

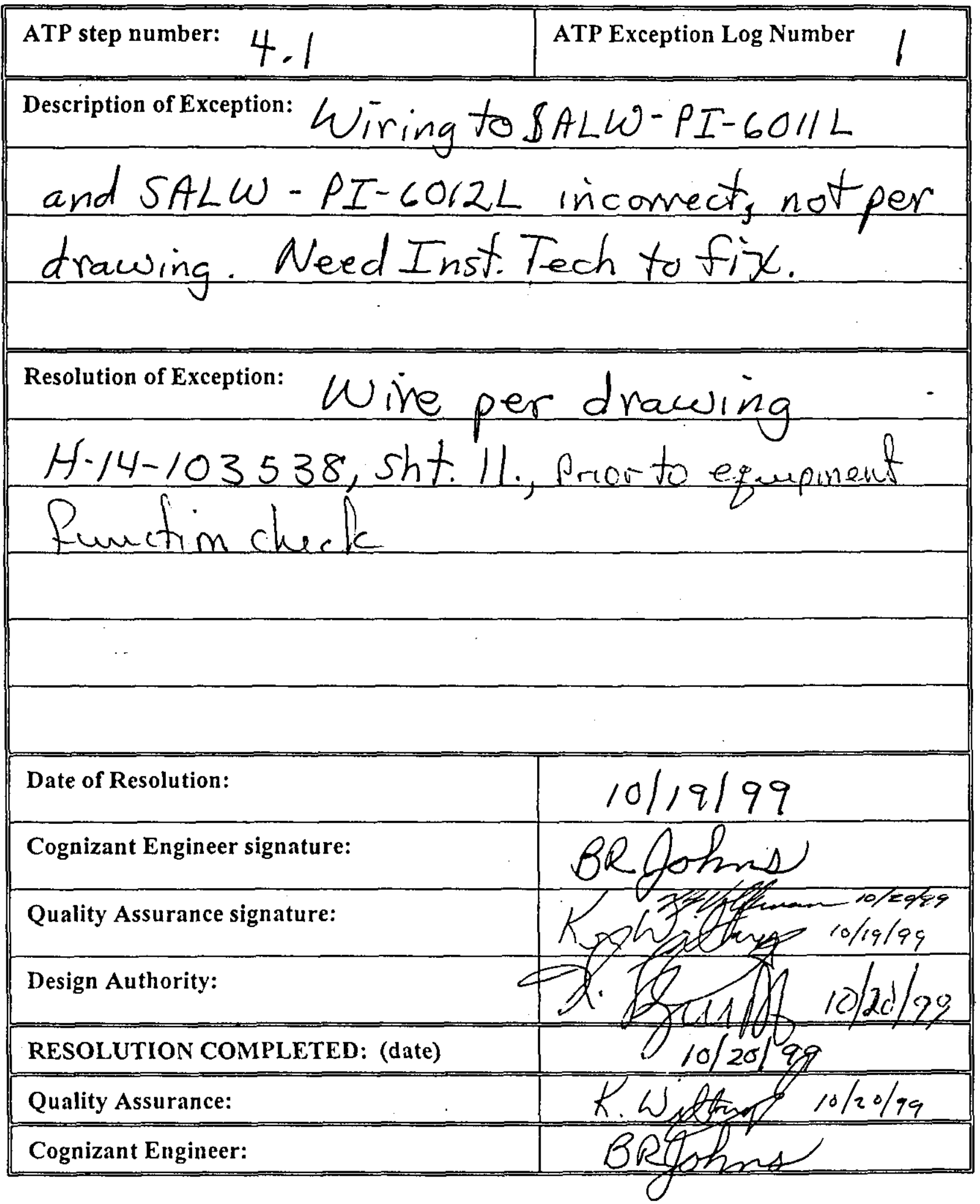


RPP-5056

REVISION 0

ACCEPTANCE TEST PROCEDURE EXCEPTION RECORD

This page may be reproduced as necessary.

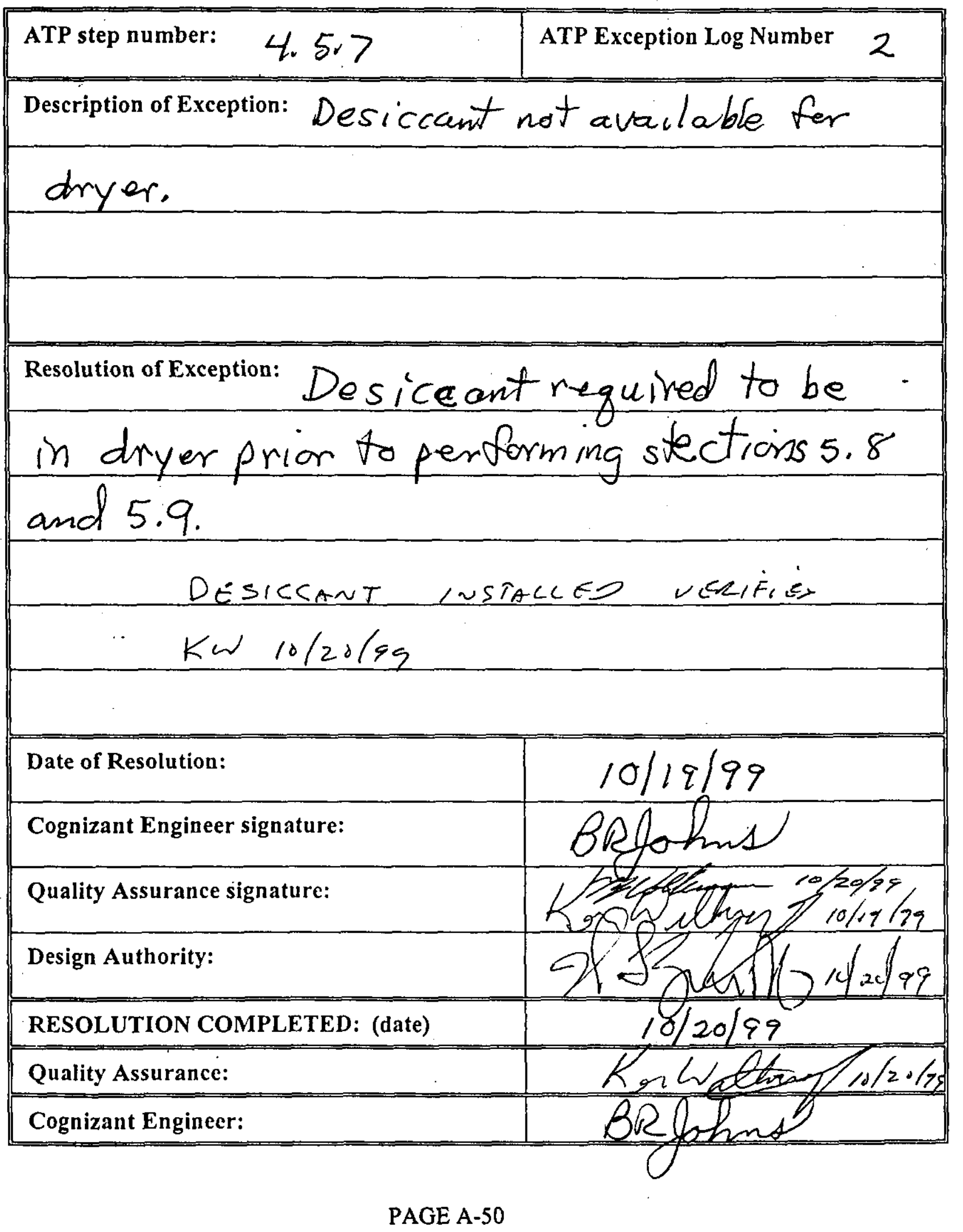

WORK ORDER $2 \mathrm{H99C}$

PAGE $123-62$ OF 
RPP-5056

REVISION 0

ACCEPTANCE TEST PROCEDURE EXCEPTION RECORD

This page may be reproduced as necessary.

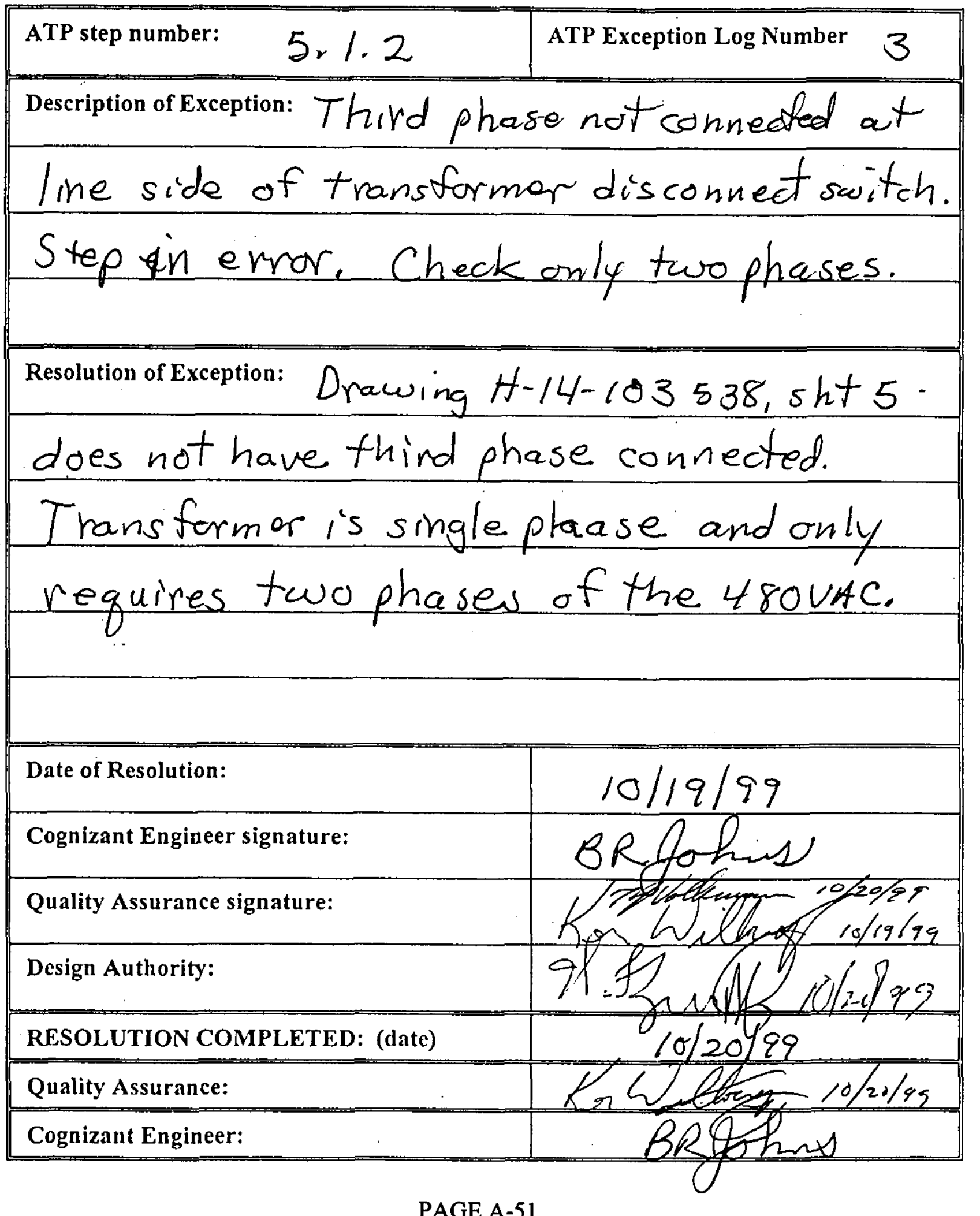

PAGE A-51

WORK ORDER 2 H $990 \ldots$ U

PAGE $123-1,2$ OF 
RPP-5056

REVISION 0

ACCEPTANCE TEST PROCEDURE EXCEPTION RECORD

This page may be reproduced as necessary.

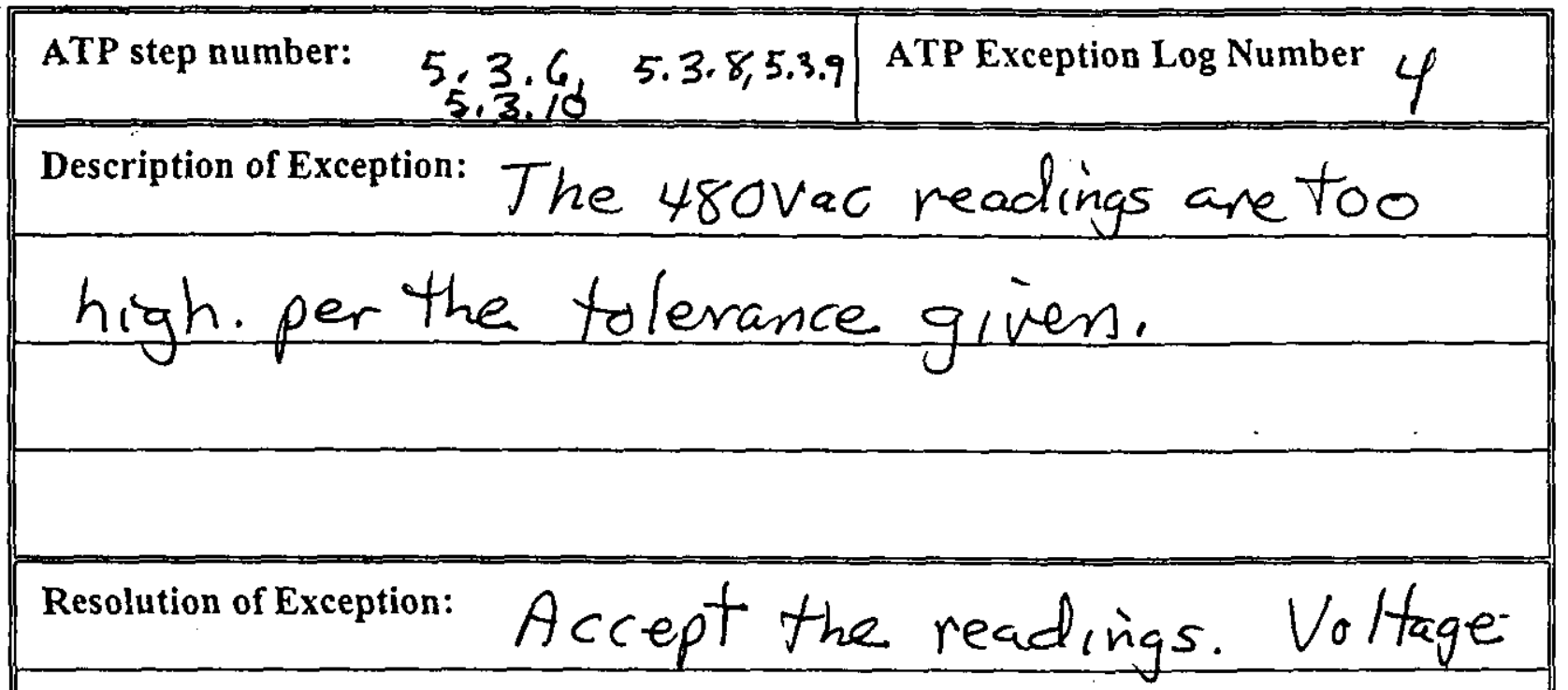

readings were taken at night. Incoming

power may be higher duets most equipment

in building sheet off. Readings on fast

skid taken during daytime were in the $480 \mathrm{vac}$ range. Voltage readings this tune were 6 vac high.

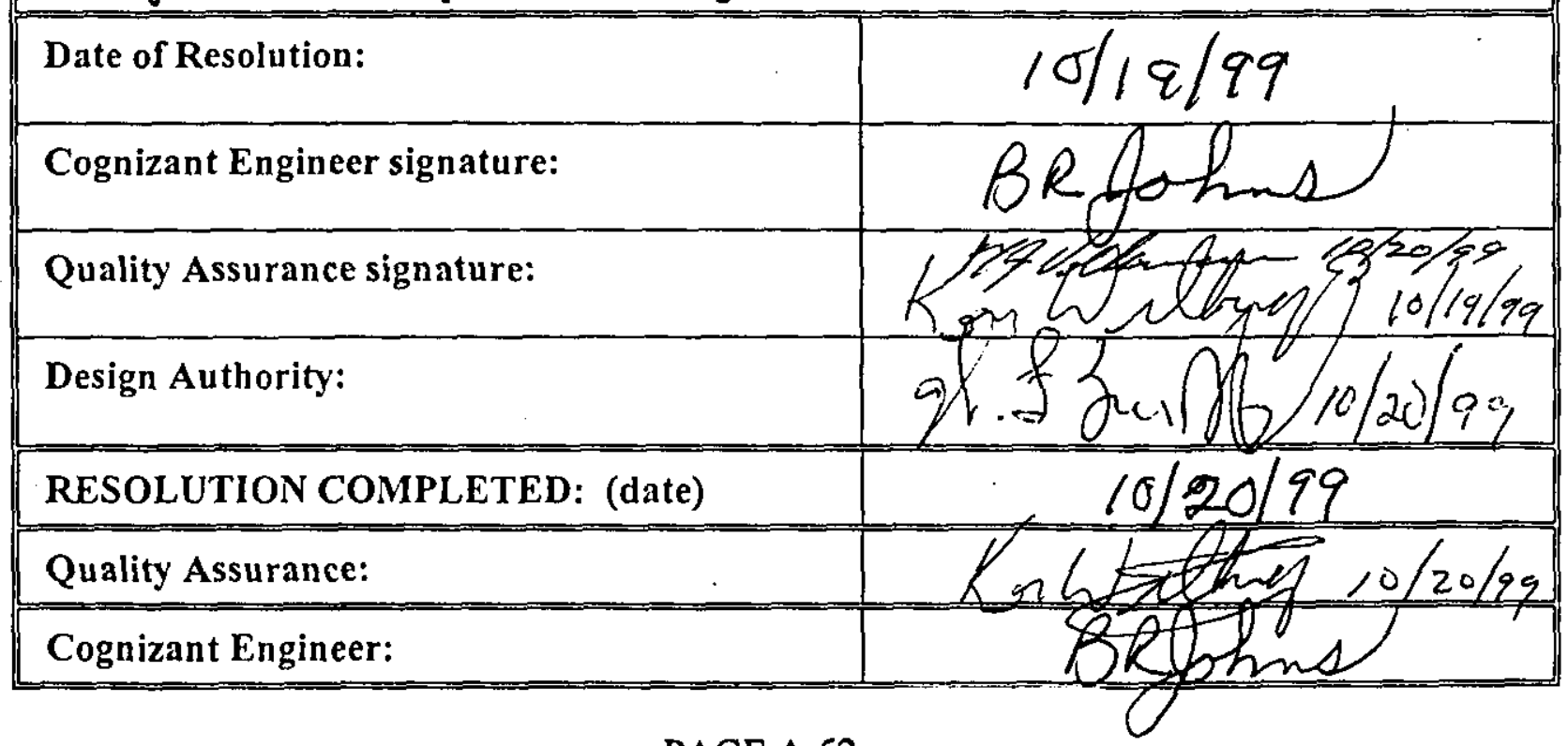

PAGE A-52

'ORE ORDER

$249903386 F$

PAGE 123-16 OF 
RPP-5056

REVISION 0

ACCEPTANCE TEST PROCEDURE EXCEPTION RECORD

This page may be reproduced as necessary.

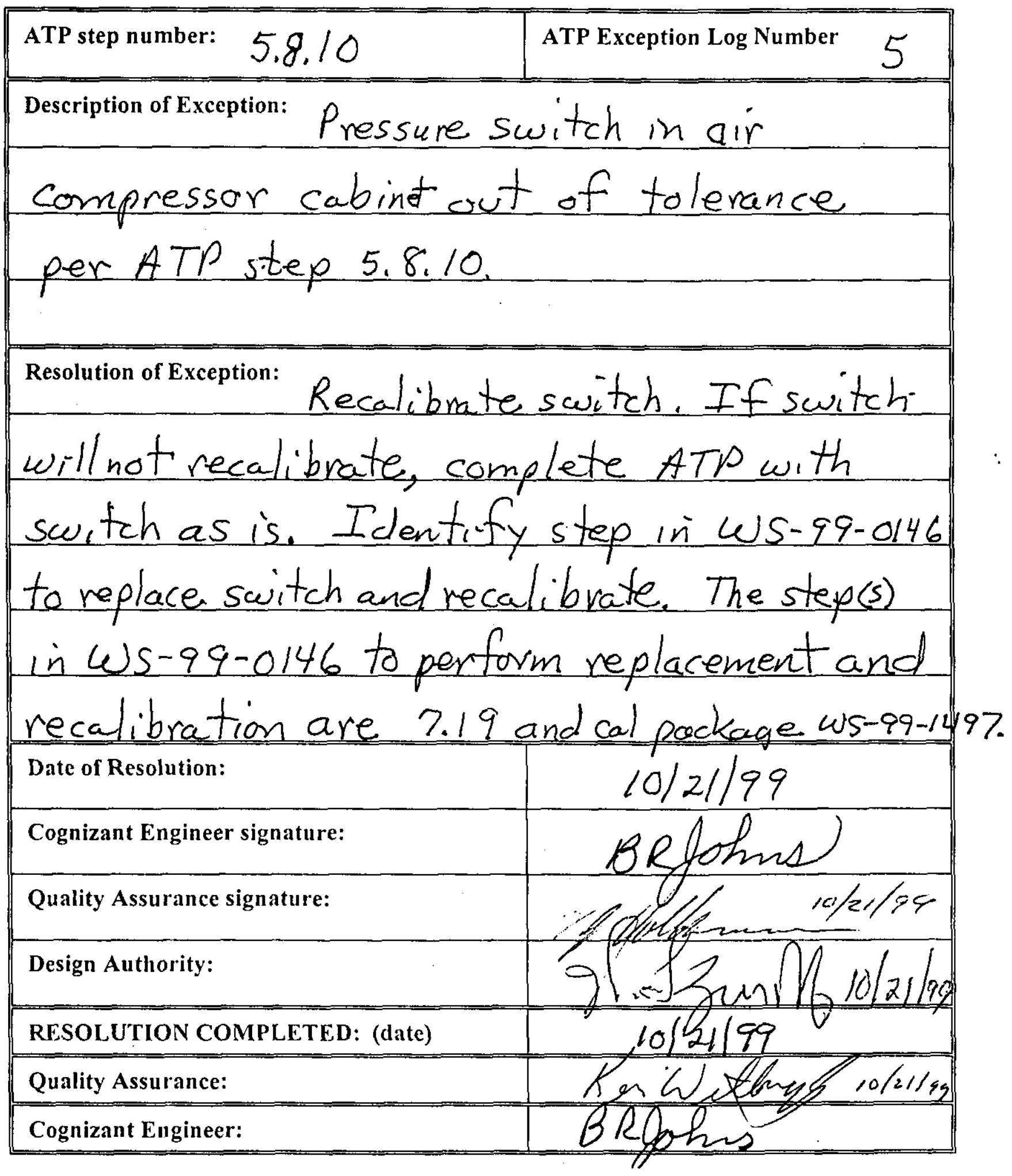

PAGE A-53 
RPP-5056
REVISION 0

ACCEPTANCE TEST PROCEDURE EXCEPTION RECORD

This page may be reproduced as necessary.

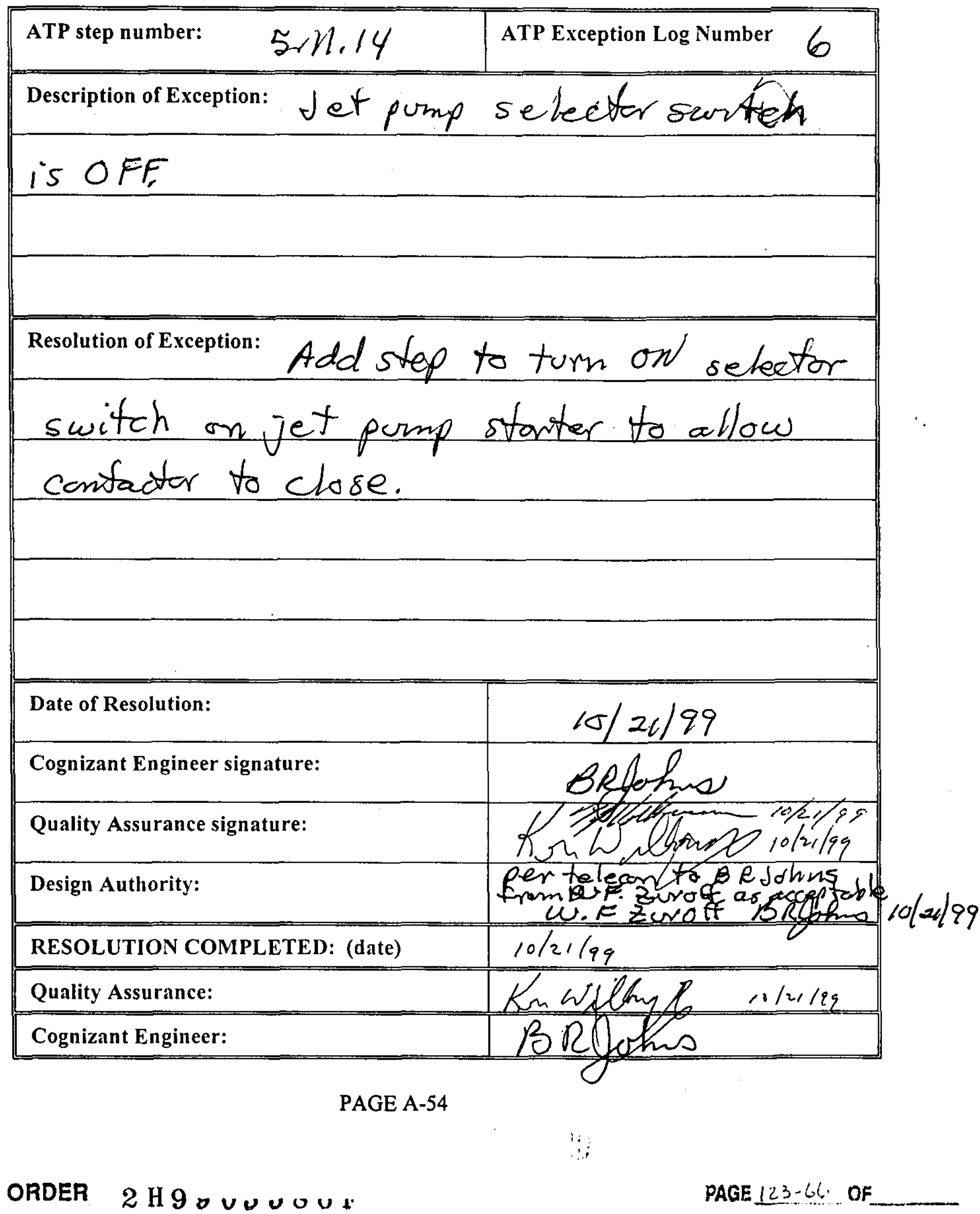


RPP-5056

REVISION 0

ACCEPTANCE TEST PROCEDURE ACCEPTANCE RECORD

This Acceptance Test Procedure has been completed and the results, including red-line changes, exceptions, and exception resolutions, have been reviewed for compliance with the intent of the Purpose (Section 1.0). The test results are accepted by the undersigned:

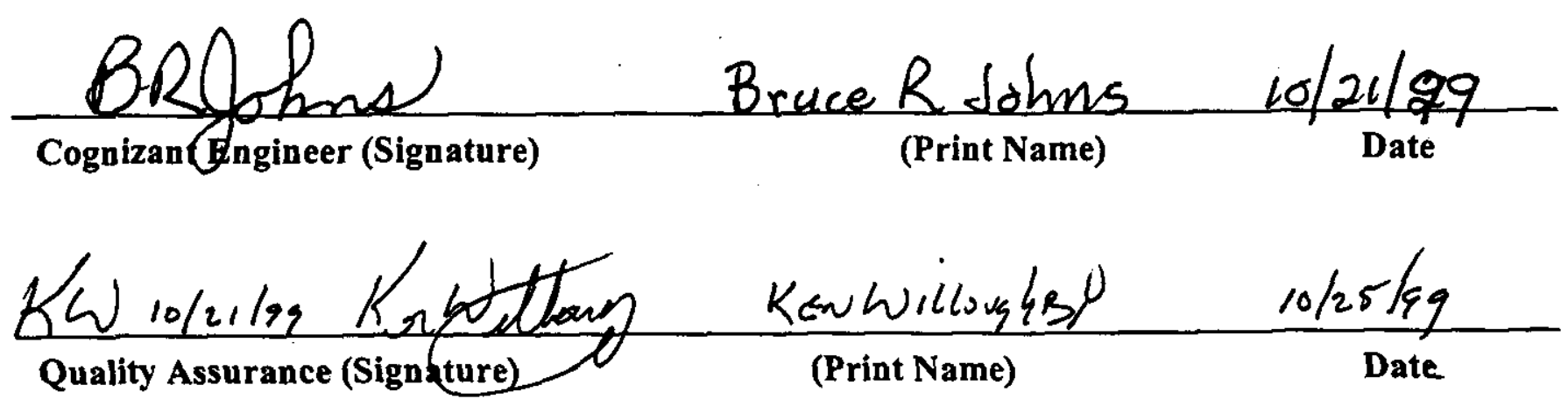

PAGE A-55

WORK ORDER $2 \mathrm{H} 9903386 \mathrm{~F}$

PACE 123-6] OF 
RPP-5056

REVISION 0

PROCEDURE PERFORMER SIGNATURE SHEET

All personnel who will be performing, initialing and signing the procedure shall enter their printed name, signature and initials below.

Bruce R. Johns BRgohns Beg KEN willoughs

IT Harris

JeEP Tucker

Mark Johnson

Cuneo Spiel

Dawiju

Dave Eddie

TH Vourmso

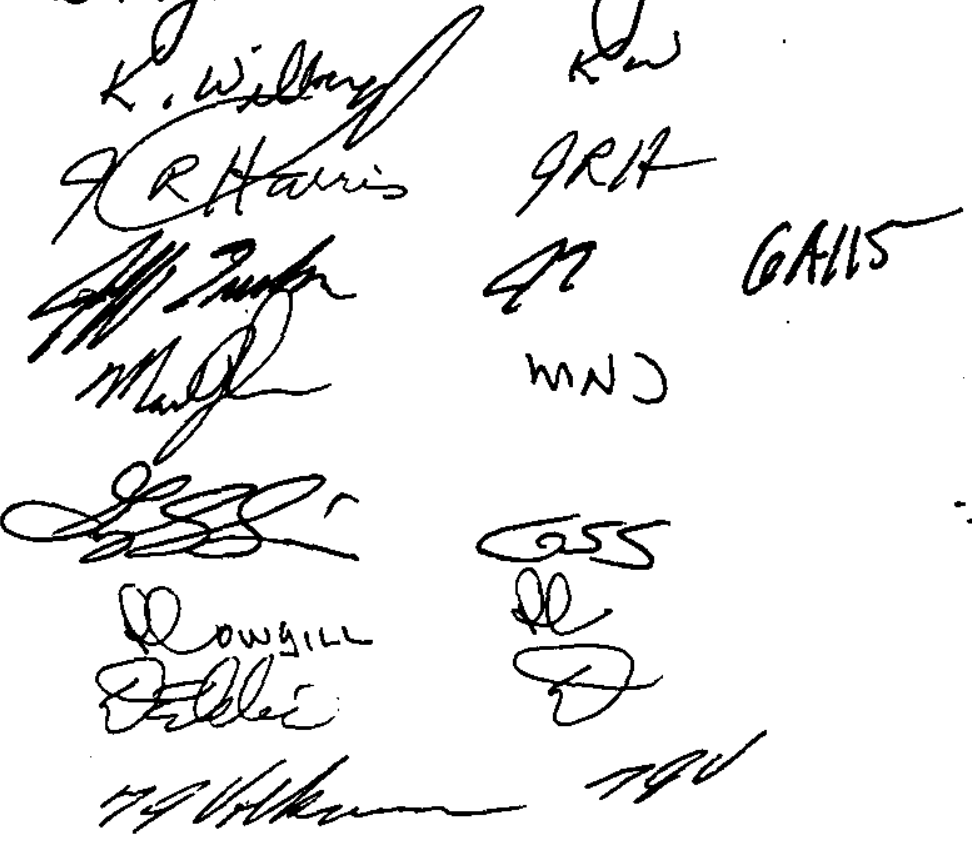

PAGE A-56

WORK ORDER

2 H $9903386 \mathrm{~F}$

PACE $123 \cdot 68$ OF 
NEC INSPECTION REPORT

REVISION 0

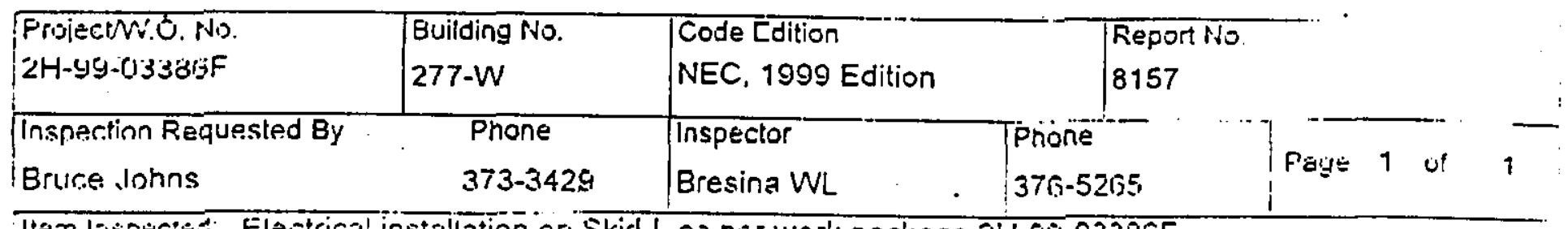

Item lispureat Electrical installation on Skid-L as per work package $2 \mathrm{H}-99-03.386 \mathrm{~F}$.

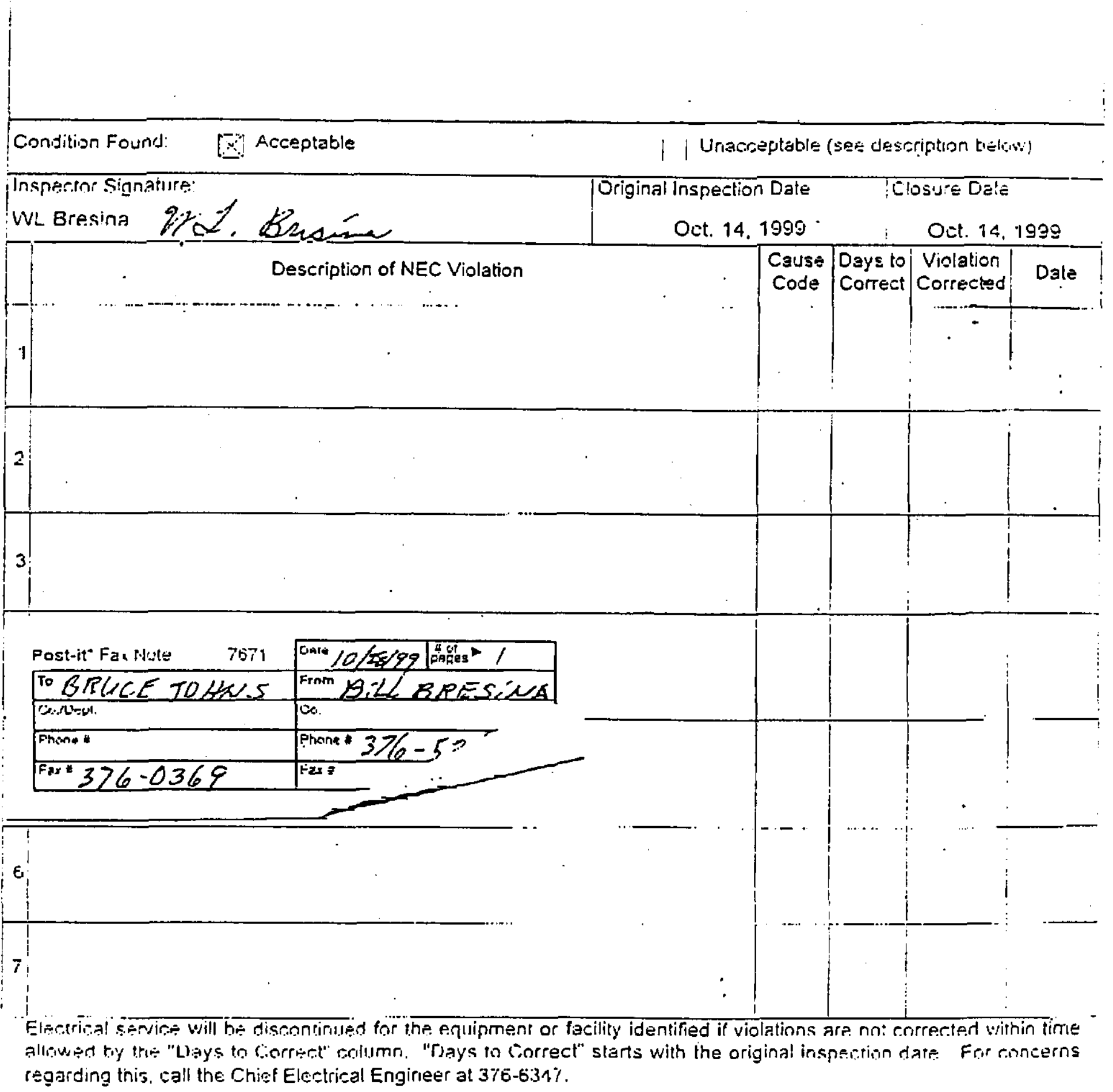

R.EH2LTOSOM

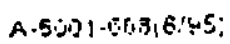

PAGE A-57 

THE HARTFORD STEAM BOHER INSPECTION AND INSURANCE COMPANY, HARTFORD, CT

TPI WO NO: 2W-99-

( 1 Hrs)

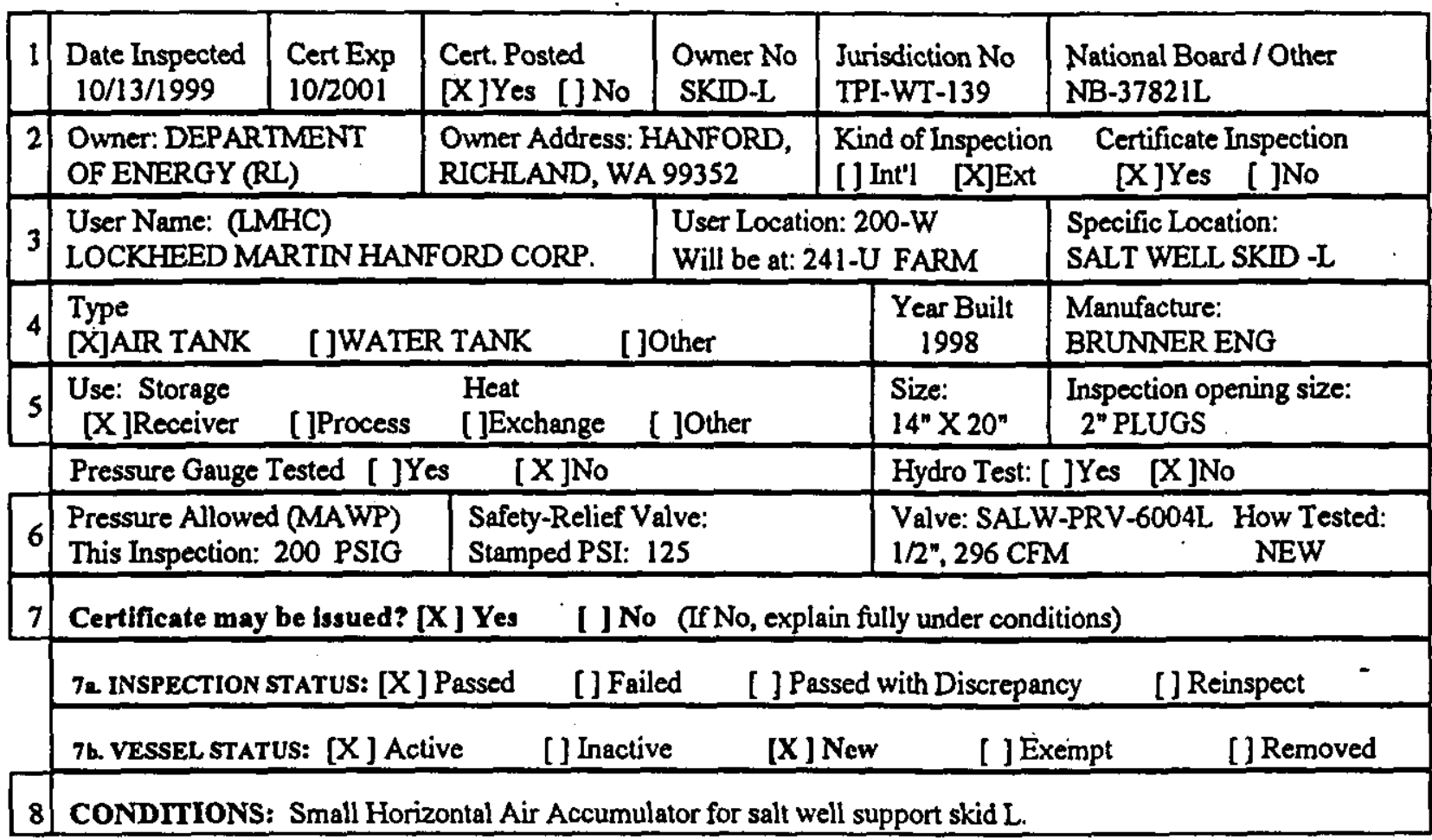

Inspected at $277-W$ Fabrication Shop during final assembly. Scheduled to be located at $241-U$ Tank U-105

8a: Internal Inspection not done or required this inspection..

Original Thickness: Shell $=\underline{0.106}$ Heads $=\underline{0.094}$

8b: External Inspection shows no dents, damage, leakage, corrosion or excess vibration.

Pressure guage: Installed \& Proper Bottom drain: Installed \& Suitable

Safety-Relief Valve Seal was intact with no evidence of damage or tampering

9 REQUIREMENTS/RECOMMENDATIONS: The following items are to be corrected:

1. None this inspection

10 Name of Facility Contact to whom requirements were explained: Douglas DeFord Tel: 373-5727

Copies to: Bruce Johns Tel: 373-3429 S7-24 David Saueressig Tel: 373-0183 57-20.

Mike Koch Tel: 373-2699 S7-24

I hereby Certify this is a true report of my inspection

Signature of Inspector

\begin{tabular}{|l|l|l|l|}
\hline John L. Densley & $\begin{array}{l}\text { Commission No } \\
\text { NB- 8032W }\end{array}$ & $\begin{array}{c}\text { Employed By: The Hartford Steam Boiler } \\
\text { Inspection and Insurance Co. }\end{array}$ \\
\hline
\end{tabular}

TPI-WT-139.doc

PAGE A-58 
THE HARTFORD STEAM BOILER INSPECTION AND INSURANCE COMPANY, HARTFORD, CT

TPI WO NO: 2W-99-

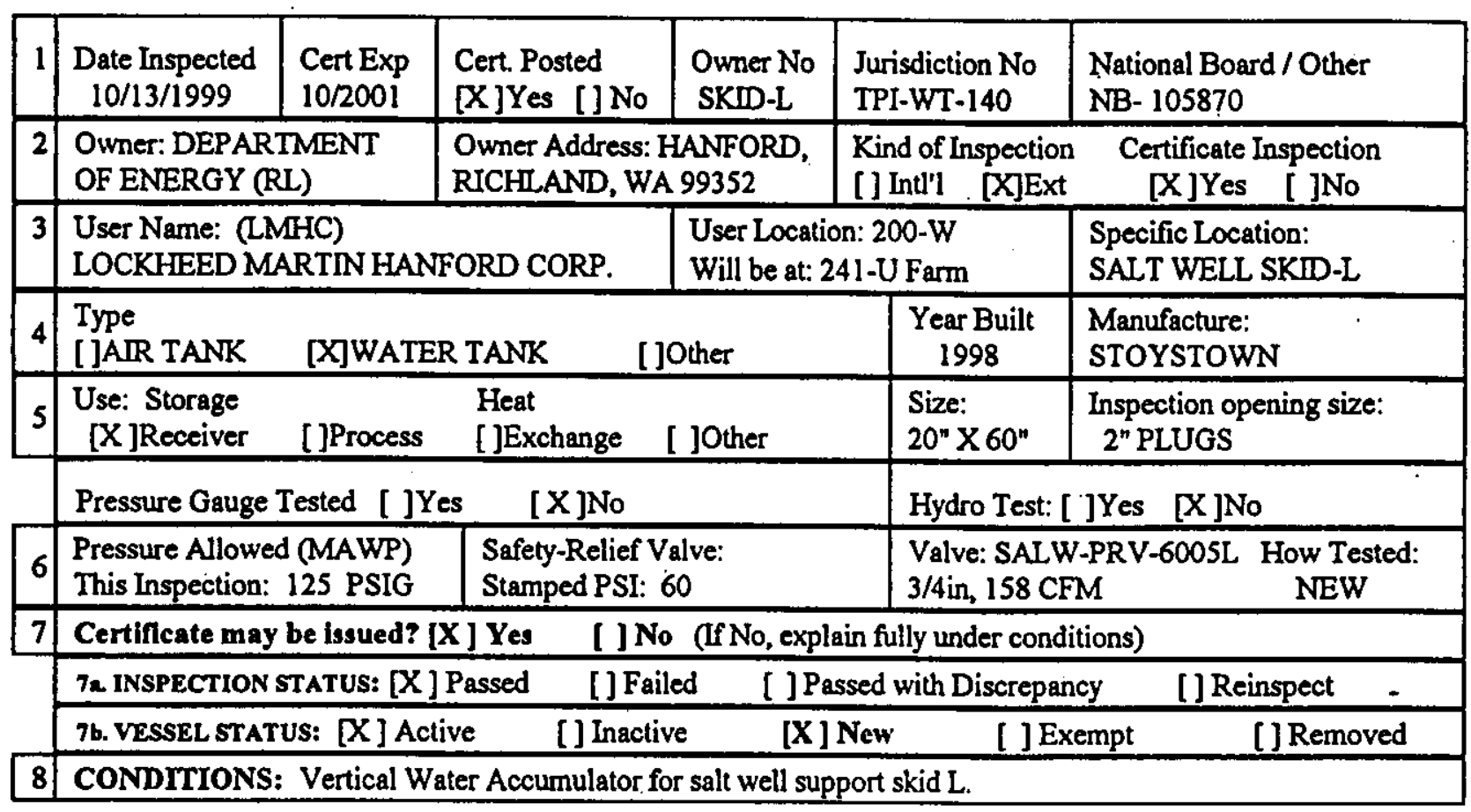

Inspected at 277-W Fabrication Shop during final assembly. Scheduled to be located at 241-U Tank U-105.

8a: Internal Inspection not done or required this inspection. Vessel is galvanized and not subject to internal corrosion.

8b: External Inspection shows no dents, damage, leakage, corrosion or excess vibration.

Pressure guage: Installed \& Proper Bottom drain: Installed \& Suitable.

Safety-Relief Valve Seal was intact with no evidence of damage or tampering

\begin{tabular}{l|l}
9 & REQUIREMENTS/RECOMMENDATIONS: The following items are to be corrected:
\end{tabular}

1. None this inspection
$10^{\circ}$ Name of Facility Contact to whom requirements were explained: Douglas DeFord Tel: $373-5727$
Copies to: Bruce Johns Tel: 373-3429 57-24 David Saueressig Tel: 373-0183 S7-20,
Mike Koch Tel: $373-2699 \quad$ S7-24

I hereby Certify this is a true report of my inspection
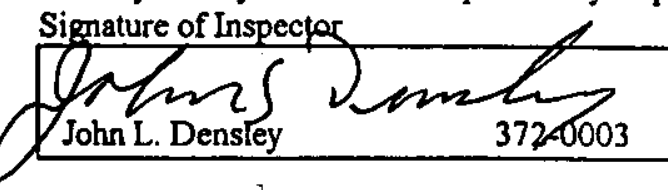

Commission No Employed By: The Hartford Steam Boiler NB- 8032W $\quad$ Inspection and Insurance Co.

TPI-WT-140.doc 